\title{
Anatolia: Turizm Araştırmaları Dergisi: 25 Yılın Öyküsü; Bir Dergiden Öte, Belki de Bir Enstitü...
}

\author{
Nazmi KOZAK* \\ *Prof. Dr., Anadolu Üniversitesi, Turizm Fakültesi, Yunus Emre Kampusu, 26470 Eskişehir \\ E-posta:nkozak@gmail.com
}

\begin{abstract}
Anlatmaya Başlarken...
Bu yazıda sizlere Anatolia: Turizm Araştırmaları Dergisi'nin 25 yıllık öyküsünü anlatmaya çalışacă̆ım. Bir çırpıda geçen, kolay gibi görünse de aslında epey zorlu yaşanılan yillar.

Anatolia'nın öyküsünü yazmak için, en başa, 1989 yılına gitmek lazım. Bunu fiziken yapmak olanaksız ama derginin ilk kurulduğu yere gitmek hala kolay. Ben de öyle yaptım. Bu ilk satırları Ankara'da, Konur sokakta bulunan Buluş Kıraathanesi'nde yazmaya başladım. Şimdilerdeki adı "Salon Buluş" olsa da, her şey yerli yerinde.. Sahipleri, masalar, ambiyans ve çalışanlar. Bundan 25 yıl önce olduğu gibi Haşim yine bir çay getirdi. Bu satırları yazmaya başladım.
\end{abstract}

Anatolia'nın öyküsü, dedim ya, 1989 yılının Eylül ayında başlar. Bu satırların yazarı o dönemde Hacettepe Üniversitesi'nde yüksek lisans öğrencisidir. 1987 yılından itibaren de Buluş Kıraathanesi'ne gitmekte, arkadaşları ile orada "buluş"maktadır. Eylül ayının ortaları olmalı. Akşamın erken saatleri, bizler; Adnan (Hastürk), Muammer (Budanur), Engin (Başçı) ve Levent (Ünal) her zamanki gibi Buluş Kıraathanesi'nin önünde oturuyoruz. Benim bir hayalim var; dergi çıkarmak. Bunu konuşuyoruz. Zaten gelirken de Konur'da yeni açılan Dost Kitabevi'ndeki dergileri incelemi-

\section{GíRiş}

Günümüz Türkiye'sinin bulunduğu topraklarda, nedendir bilinmez gelişim, her zaman "etki-tepki" mekanizmasının sonuçlarından biri olarak ortaya çıkar. Çok eski dönemleri bir yana bırakalım, son 150 yılın gelişmelerinin hep bir "etki-tepki" mekanizmasının sonuçlarına bağlı olarak şekillendiği görülüyor. Turizmle ilişkili konularda da durum pek farklı değil. Cumhuriyet öncesinde ve Cumhuriyet sonrasında "Batılılaşma" çabasının birer sonucu olarak turizmle ilişkili alanlarda gelişmeler ortaya çıktı. Çok gerilere gitmeden konumuza şim, her zamanki gibi. Yeni dergiler çıkmaya başlamış. Türkiye 12 Eylül'ün üzerine yı ̆̆dı ̆̆ı ölü topră̆̆nı atmaya çabalıyor. Yeni dergiler, yeni açılımlar.. Bir kısmı günümüzde de yayımlanan dergiler bunlar.

Dedim ya, turizm alanında bir dergi çıkarmayı konuşuyoruz. $B u$ arada her zaman olduğu gibi Haşim tepsisinde kalan son çayları bize veriyor! Bir yandan da gelene geçene bakıyoruz. Dergi konusu ciddileşmeye başlıyor. "Konusu ne olsun?", "yazarları kim olsun?", "boyutu ne olsun?" derken "adı ne olsun?" sorusuna kadar geliyoruz. Birtakım isimler ortaya atıliyor. Bu arada Levent "Anatolia" olsun diyor. Herkes de kabul ediyor. İçeriğine gelince, yalnızca turizm olmasın, çevre de olsun, kültür de olsun deniliyor. Bunda da mutabık kalınıyor. Sonrasında günler boyunca tartışmalar Haşim'in çayları eşliğinde sürüyor. Kasım 1989'da yazılar derlenmeye başlanıyor. Aralık ayında bask işini düşünmeye başlıyoruz. Maltepe Camii'nin karşısında küçük bir matbaa buluyoruz; Doruk Ofset, bütçemize de uygun. Ve Ocak 1990 başlarında ilk sayı basılıyor. Buluş Kıraathanesi uzun yıllar bizim büromuz oluyor; randevularn orada kabul ediyoruz, Buluş Kıraathanesi'nin telefon numarasinı büromuzun telefonu gibi kullanıyoruz.

Ve hikâye böyle başlıyor. Bir bakmışız 25 yıl geçivermiş.

1950'lerle başlarsak, Batılı ülkelerle girişilen siyasi ve ekonomik ilişkiler turizm sektörünü de etkiler, bu alanda yatırımlara başlanmasına yol açar. İstanbul Hilton Oteli, T. C. Turizm Bankası A. Ş. ve işletmeleri, Emek otelleri ve 1960'lardan sonra hizmete giren diğer turizmle ilgili işletmeler de Batıyla kurulan ilişkilerin birer sonucudur.

1960'lardan sonra turizmin ayrı ve ayrıcalıklı bir konu olarak makro politikalarda yer almaya başlaması, bu alanla ilişkili pek çok alanı etkiler, bir sinerji oluşturur. 1950'lerde devlet İsviçre'de burslu otelcilik eğitimi alacak istekli öğrenciler bile bu- 
lamaz iken 1960'lardan itibaren turizm ve otelcilik eğitimi müstakil kurumlar olarak kendini göstermeye başlar. Ankara Otelcilik Lisesi, Ticaret ve Turizm Yüksek Öğretmen Okulu, Ege Üniversitesi Turizm Enstitüsü, İstanbul Üniversitesi İktisadi Coğrafya ve Turizm Enstitüsü ve 1970'lerde kurulan pek çok önlisans ve lisans programlara ek olarak yüksek lisans programlarının açılması, Batıyla kurulan ilişkilerin birer sonucu olarak ortaya çıarlar.

Ülkemizde turizmle ilgili akademik içerikli gelişmeleri "1960-1975", "1976-1990", "1991-2000" ve "2001 yılı sonrası" olmak üzere dört ayrı dönem olarak incelemek mümkündür. Elbette bu dönemlerin turizm sektörünün gelişimi ile ilgili önemli örtüşmeleri de bulunuyor.

1960-1975 yılları, akademik içerikli programların ilk örneklerinin ortaya çıtığı, bu alanda ilk akademik çalışmaların yapıldı $\breve{g}_{1}$, kitapların ve tezlerin hazırlandığ 1 bir dönemdir. Bu dönem bir anlamda Batı Avrupa'daki akademik kurumların ve akademik anlayışın turizm alanında da ülkemizde uygulanmaya geçirilmesi çabalarının olduğu yıllardır. Bu dönemin bütün önemli aktörleri eğitimlerini Batı Avrupa'da alırlar.

İkinci dönem 1976-1990 yıllarını içermektedir. Bu dönemin karakteristik özelliği, akademik kurumlaşmanın daha ileri boyutlarda yaşanmasıdır. Hacettepe, Boğaziçi, Ege, Uludağ ve Çukurova üniversitelerinde önlisans ve lisans düzeylerinde ilk akademik kurumlar bu dönemde eğitime başladılar. Ek olarak, yüksek lisans düzeyindeki ilk turizm programları da bu dönemde açılır. Akademik çalışmaların içeriğine bakıldığında, ilk döneme oranla daha nitelikli, daha spesifik konuların araştırmalarda konu edildiği, hazırlanan lisansüstü tezlerin sayıca arttığı ve bu alanda akademik kongrelerin düzenlenmeye başlandığı görülüyor. Bu dönemin belki de en önemli göstergelerinden biri de Turizm İşletmeciliği Dergisi ile 1986'dan itibaren de Turizm Yıllığı serisinin yayımlanmasıdır. Her iki yayın ülkemizdeki turizm araştırmalarının ulaştı̆̆ gelişimi gösteren mihenk taşlarıdır.

Üçüncü dönem olan 1991-2001 yılları, Türk turizm araştırmalarında önemli bir kırılmanın yaşand1$\breve{g}_{1}$ yıllardır. Turizm eğitimi ve araştırmaları Kıta Avrupası'nın etkisinden kurtulur, ama bir başka etkinin altına, Amerika Birleşik Devletleri (ABD) odaklı turizm eğitim ve araştırmalarının uydusuna girer. Günümüze değin geçen 25 yıllık dönem- de artısıyla eksisiyle ABD odaklı turizm eğitim ve araştırmalarının belirleyiciliği söz konusudur. 1990-2001 dönemini diğer dönemlerden farklılaştıran diğer konular arasında, akademik turizm programlarının (önlisans, lisans ve lisansüstü) hızlı bir şekilde artmaya başlaması, bu alanda düzenlenen akademik kongrelerin çeşitlenmesi ve artı̧̧ göstermesi, hazırlanan lisansüstü tezlerin ve yayınlarda hızlı bir artışın içine girilmesi sayılabilir. Bu dönemin diğer önemli bir farklılığı da hazırlanan lisansüstü tez ve araştırmalarda görgül araştırma yaklaşımlarının ezici bir üstünlükle, bilinçli veya bilinçsiz ve en önemlisi de "sı ğ" bir şekilde kullanılmaya başlamasıdır. Anatolia: Turizm Araştırmaları Dergisi üçüncü dönemin tam başında yayımlanmaya başlar. 1997 yılından itibaren yayın yaşamına girecek uluslararası Anatolia dergisi ise, dördüncü dönemin belirleyicilerinden biri olacaktır.

Son dönem 2001 yılından sonrasına tekabül etmektedir. Bu dönemde akademik turizm programlarının sayıca artışı devam eder; hazırlanan lisansüstü tezler, yayınlar ve akademik kongrelerin sayıca artmasına ek olarak, spesifik bilimsel toplantıların da periyodik olarak düzenlenmeye başladığı görülmektedir. Pek çok akademisyenin ileri sürdüğü bir görüşün aksine, 2001 yılında turizm alanının doçentlik temel alanı olmaktan çıkarılması, bu alandaki araştırmaların ve yayınların niteliğini olumlu yönde etkilemiştir. Tezat gibi görünen bu durum, ne yazık ki doğru bir tespittir. Bu gelişmenin görülebilmesi için hazırlanan bibliyometrik araştırmaların bulgularının incelenmesi yeterlidir. 2001 sonrası dönemin diğer bir belirleyicisi de, 1990'larda yurtdışına gönderilen lisansüstü öğrencilerin karar verici veya turizm araştırmalarını yönlendirici basamaklara erişmeleridir. Bu durum, turizm araştırmalarının niteliği üzerinde önemli etkiler yapar. 2001 sonrası dönem uluslararası alanda Türk turizm araştırmacılarından söz edildiği yıllar olması da üzerinde durulması gereken bir gelişmedir.

2014 yılında 25. yayın yılını kutlayan Anatolia: Turizm Araştırmaları Dergisi, 1990 sonrası dönemin bir ürünü olarak ortaya çıkmış; yayın yılını izleyen dönemde turizm araştırmalarının yönlenmesinde, hem bir akademik dergi olarak hem de düzenlediği bilimsel etkinlikler ile başat katalizör haline gelmiştir. Yazının bundan sonraki bölümlerinde, Anatolia'nın bir dergi olarak başladığı, ancak enstitü düzeyindeki kurumların ancak gerçekleştirebi- 
leceği çalışmaları ortaya çıkarmasının öyküsüne ve gelişimindeki önemli yapıtaşlarına yer verilecektir.

\section{YAYIMLAMA KARARI}

Önceki sayfalarda açıklanan gelişmeler, elbette ki Anatolia'nın yayımlanmasına giden yolda önemli aşamalardır. Turizm alanında ulusal bir bilimsel dergi eksikliği küçük bir akademisyen grubu tarafından hissedilmiş olsa bile, akademik birikimin kuşaktan kuşağa aktarımı olmadan Anatolia da olmazdı. Dolayısıyla, Anatolia'nın yayımlanmasinda ilk olarak bu satırların yazarının Hacettepe Üniversitesi'nde yüksek lisans çalışmasına başlaması önemli bir unsurdur. Lisansüstü çalışmalar sırasında yurtdışında benzer yayınların olması, bu satırların yazarı gibi o dönemin akademisyenlerinin en azından bir bölümü tarafından ülkemizdeki bir eksiklik olarak algılanırdı. Kısa süren bir deneyim olsa bile Turizm İşletmeciliği Dergisi'nin 1978-1981 yılları arasında yayımlanması, Turizm Yıllı̆̆ı'nın 1986 yılında yayımlanmaya başlaması Anatolia'nın doğmasına yol açan önemli yapıtaşlarıdır.

Kasım-Aralık 1993 tarihli editöryal bir yazıda derginin yayım kararı şöyle açıklanmış:

\begin{abstract}
“... Birkaç yıl önce bir üniversitenin turizm bölümündeki lisansüstü öğrenimimiz sırasında sık sık karşılaştığımız Türkçe yayımlanan bir turizm araştırmaları dergisinin yokluğu, bizleri hep rahatsız ederdi. 'Niye bizim de böyle bir yayınımız olmasın?' görüşünden hareket ederek, önce bu görüşümüzü bazı hocalarımıza açtık, ancak, önerimiz ciddiye alınmadı. Durum böyle olunca kendi başımıza bu işi yapmaya karar verdik"
\end{abstract}

Bu konudaki bir diğer etki de ülkemizin 1990'lardaki siyasi durumudur. O dönem anımsanacak olursa, 12 Eylül'ün getirdiği dar siyasal ortamın genişlemeye başladığ 1 , toplumun nefes almaya başladığı yıllardır. Ankara'nın Türk entelektüel yaşamına olan katkıları henüz sona ermemişti. Hemen her gün Ankara'nın bir köşesinde siyasi, sosyal ve edebiyatla ilgili konulardan oluşan paneller, konferanslar ve seminerler yapılmakta ve çok sayıda izleyiciyi de bu toplantılara katılmaktaydı. 19891991 döneminde bu toplantıları kaçırmayanlardan biri de bu satırların yazarı idi. Elbette bizler de Ankara'nın o dönemdeki coşkulu ve fikri ortamından epey etkilendik.

\section{YAYIM BILLGILERI}

Bütün bu gelişmeler ve etkileşimler içerisinde Anatolia'nın ilk sayısı 1990 yılının Ocak ayında ya- yımlandı. Eylül 1989 tarihinde yayım kararı alınan derginin ilk yazıları Kasım 1989 tarihinde derlenmeye başlandı. İlk sayı Ocak 1990'da baskıdan çıtı. İlk günden bu güne derginin teknik özellikleri pek çok kez değişikliğe uğradı. Bundan sonraki açıklamalarda derginin birtakım teknik özellikleri üzerinde durulacaktır.

İlk sayılardaki künye bilgileri: Derginin sahibi, bu satırların yazarı gibi, Hacettepe Üniversitesi Turizm İşletmeciliği Yüksek Lisans Programı'nda öğrenci olan Adnan Hastürk'tür. Editörlüğünü ise bu satırların yazarı olan Nazmi Kozak yerine getirdi. Genel Yayın Yönetmeliği'ni de Ankara Üniversitesi Basın-Yayın Yüksekokulu'nda yüksek lisans yapan Engin Başçı üstlendi. Derginin künyesi yaklaşık bir yıl böyle devam etti. O dönemde Ankara Emniyet Müdürlüğü Basın Masası'na verilen dosyada derginin adı Anatolia: Turizm ve Çevre Dergisi şeklinde yer aldı. Merkezi Ankara, türü ise mesleki dergi olarak beyan edildi. Sonraki yıllarda dergilere zorunlu ISSN verilmesi uygulaması ile 1300-4220 numarası alınd1.

Sahibi: Derginin sahipliği görevini Adnan Hastürk 1990-1992 (sayı: 6-7) yılları arasında yerine getirdi. 1992 yılının 7-8. sayısından itibaren 1996 yılının başına kadar sahipliğini, editörlüğünün yanı sıra Nazmi Kozak yerine getirmeye başladı. Bu tarihten sonra derginin sahipliğinde dönemsel olarak sık sayılacak değişimler oldu. Cem Çağlar 1997 (3-4) ile 1998 (3-4) sayıları arasında, Hüseyin Yıldırım 1999 (1-2) ila 1999 (3-4) sayılarında derginin sahipliğini yerine getirdi. Turhan Kitabevi'nin sahibi Turhan Polat ise 2000 (1-2) sayısında derginin sahibi olarak künyede yer aldı. Bu sayıdan itibaren Hüseyin Yıldırım günümüze kadar derginin sahipliği görevini sürdürüyor. Derginin sorumlu yazı işleri müdürlüğünün yanı sıra editörlük görevi Nazmi Kozak tarafından 25 yıl kesintisiz yerine getirildi.

Basıldığı matbaalar: Dergi, ilk sayısından itibaren çeşitli matbaalarda basıldı. Sırasıyla Doruk Ofset, Özyurt Matbaası, MNA Ofset, İM Matbaacılık ve Sistem Ofset'te derginin basıldığını biliyoruz. Sonraki yıllarda dergide matbaa ismine yer verilmediğinden basıldığı yerlerle ilgili somut veriler bulunmuyor.

Derginin adı: Derginin 1990 - 1991 yılları arasındaki adı "Anatolia: Aylık Turizm ve Kültür Dergisi" iken 1991 yılında adı "Anatolia: Aylık Turizm, Çevre 


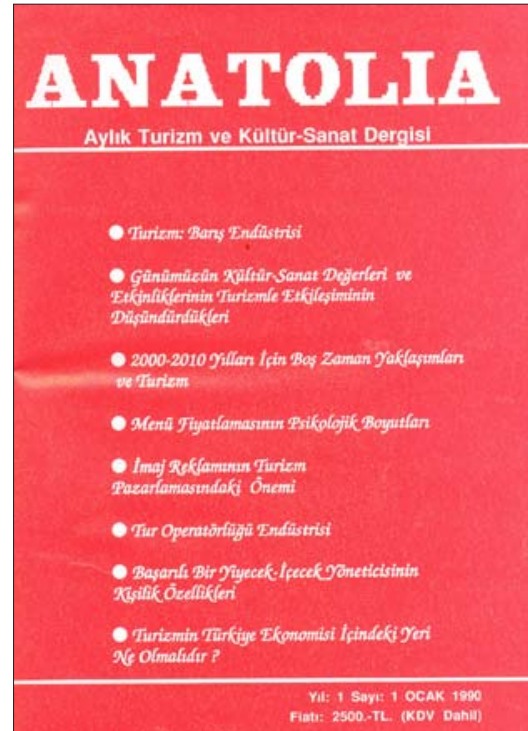

Fotoğraf 1. Anatolia'nın ilk sayısı

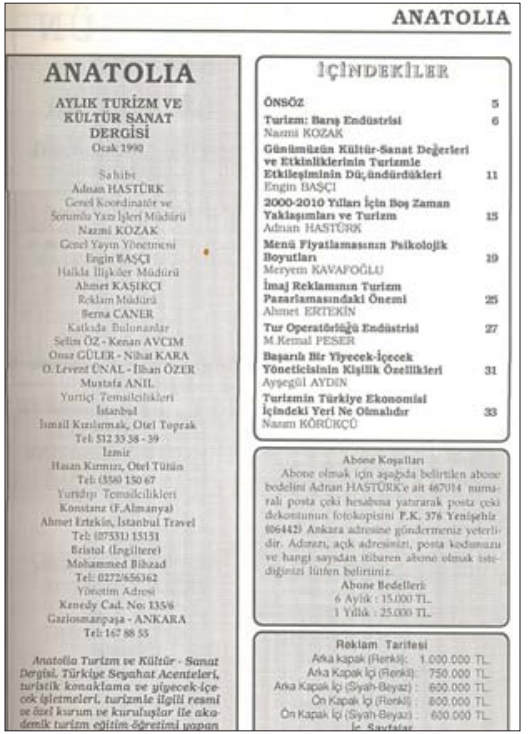

Fotoğraf 2. İlk sayının künye sayfası

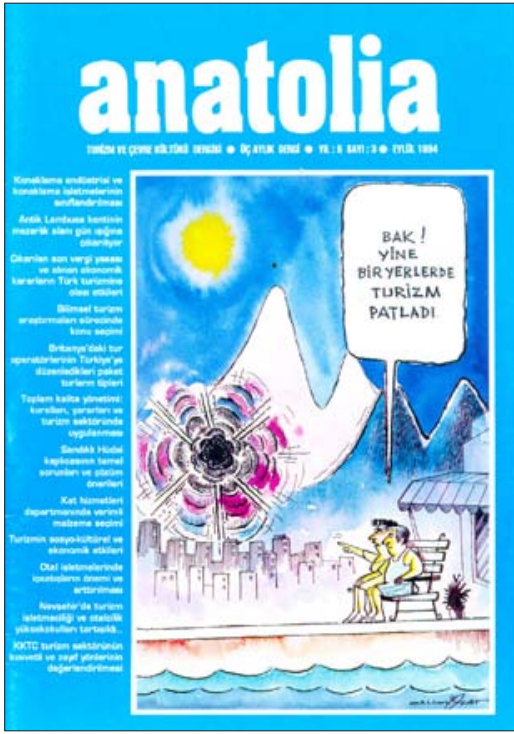

Fotoğraf 3. Anatolia'nın Eylül 1994 sayısı. ve Kültür Dergisi" olarak değişikliğe uğradı. EylülEkim 1991 sayısında dergi isminde bir kez daha değişikliğe gidilerek adı "Anatolia: Turizm ve Çevre Kültürü Dergisi" oldu. 1995 yılının Mart ayından itibaren derginin adı "Anatolia: Turizm Araştırmaları Dergisi" şeklinde değiştirildi ve bu isim halen aynı şekilde devam etmektedir.

Derginin yayımlanma aralı̆̆ı: Anatolia, 1990 yılında aylık dergi olarak yayın yaşamına başladı. 1991 yılının Kasım-Aralık sayısından 1993 yılının Kasım-Aralık sayısına kadar iki ayda bir yayımlandı. 1994 yılının Ocak-Haziran sayısından 1997 yılının Eylül-Aralık sayısına kadar ise üç aylık dergi olarak yayın yaşamını sürdürdü. 1998 yılından itibaren ise yılda iki sayı yayımlanmaya başladı. Halen bu şekilde yayım yaşamına devam etmektedir.

Derginin mizanpajı: Dergi, ilk sayısından itibaren $19,5 \times 27,5 \mathrm{~cm}$. boyutlarında, iç sayfalarda iki sütunlu olarak yayımlandı. Halen de aynı şekilde yayımlanmaktadır. Derginin basım renklerinde dönemsel ve derginin yayın politikasına bağlı olarak değişiklikler oldu. İlk yıllardaki bazı sayılarda (Mayıs-Haziran 1992 ile Kasım-Aralık 1993 arasında) iç sayfalar renkli basıldı. 1994 yılından itibaren bugüne kadar iç sayfalar siyah-beyaz basilıyor.

Kapak sayfaları: Derginin ilk sayısından 1992 yılına kadar kapak sayfası zemin üzerine tek renkli olarak basıldı. Temmuz-A ğustos 1992 sayısından sonra kapak sayfaları (iç ve dış kapak olmak üzere) renkli olarak basılmaya başlandı. Halen de aynı şekilde yayımlanmaktadır.

\section{YAYIN POLITIKASI}

Derginin yayın politikası ilk sayısından itibaren 1997 yılının sonuna kadar birtakım değişikliklere uğradı. Bununla birlikte derginin ilk sayısında açılanan yayın politikasının özü hiçbir zaman değişmedi. Derginin ilk sayısında yayın politikası şu şekilde açıklanmış:

“.... Turizm olgusuna değişik açılardan yaklaşan, yenilik getiren uygulamaları tanitan ve yeni tezler sunan yazılarla... Türk turizm endüstrisine yönelik olarak hazırlamakta olduğumuz bu dergi ile ülkemizde turizmi çeșitli yönleri ile incelemek, konuyla ilgili özellikle yurt dışındaki uygulamaları sektöre tanıtmak ve ülkemizde turizmin gerçek anlamıyla bilinmesini sağlamak... Anatolia Dergisi, turizm ve etkileşim içinde olduğu kültürsanat alanlarına ilişkin teknik, bilimsel ve güncel konulara ilişkin yazıları...." (Ocak 1990).

Görüldüğü üzere derginin ilk sayısında belirtilen yayın politikasında turizme disiplinlerarası bir anlayış ile yaklaşılacağ 1 vurgulanıyor. Derginin 25 yıllık yayın yaşamında bu amaç sürekli gözetildi.

Derginin ilk yıllarında turizm ve çevre ilişkileri yayın politikasında önemli yer tuttu. Pamukkale, Gökova ve Kapadokya yörelerinde turizmin çevre üzerindeki olumsuz etkileri 1990-1994 yılları arasinda yayımlanan yazılarda yoğun bir şekilde yer aldı. Ancak 1995 yılından itibaren akademik ko- 
nular giderek artan bir şekilde dergide yer almaya başladı. "Tezler keşfedilmeyi bekliyor", "Dünya'da yayımlanan turizm dergileri" ve "Akademik başarı ve bilim ahlakı" başlıklı editöryal yazılar, bu değişimi ortaya koyuyor. 1998 yılından itibaren ise derginin "hakem-denetimli" yayımlanmasıyla birlikte akademik konular daha da yoğun ve kapsamlı olarak yer almaya başladı. "Akademik yükseltme sistemi", "Doçentlik jürileri", "Türkiye'nin turizm araştırmalarında dünyadaki yeri, yükselişi" ve "Doçentlik sinavlarında yeni dönem" başlıklı editöryal yazılar bu değişimi gösteriyor.

\section{FINANS KAYNAKLARI}

Derginin ilk birkaç sayısı, o dönemde bazı arkadaşların kişisel katkıları ile yayımlandı. Her ne kadar ikinci sayısından itibaren ilan alınmaya başlansa da alınan ilanların giderleri karşılaması mümkün olmadi. Bununla birlikte ilk altı aydan sonraki sayılar genel olarak alınan ilan gelirleri ile yayımlandı.

Dergiye alınan ilk ilan, Turban Turizm A. Ş.'ye aitti. Halen de dostluğumuzun devam ettiği Dr. Mehmet Özdemir'in o yıllarda Turban Turizm A. Ş.'de genel müdür pozisyonunda görev yapıyor olması ile bu ilanı almıştık. Turban Turizm A. Ş.'den toplam olarak iki ilan almışız. Derginin hemen bütün sayılarında bu satırların yazarının veya bazı dostların kişisel ilişkileri ile ilan alabildik. Bu bağlamda Dr. Mehmet Özdemir'in Turban Tu- rizm A. Ş.'deki görevinden ayrıldığı yıllardan itibaren (1992) yakın zamana kadar derginin yaşatılması için özverili katkıları oldu. Dr. Mehmet Özdemir, Anatolia'nın bugünlere gelmesinde en büyük katkıy1 yapan kişidir. Daha sonra dergiye en çok katkı yapanlar arasında Prof. Dr. Mithat Üner ile geçtiğimiz yıl Prof. Dr. olan İbrahim Birkan yer alır. Her iki dostumuz da gönülden Anatolia'ya destek oldular. Anatolia'nın yaşatılması konusunda isimleri zikredilmesi zorunlu olan diğer iki kişi de Doç. Dr. Kemal Birdir ve Prof. Dr. Mehmet Yeşiltaş'tır. Her iki dostumuz da derginin eski dönemlerinden itibaren destek oldular.

\section{Yayımlanan İlanlar}

Dergiye pek çok kurum ve kuruluş ilan verdi. Toplam 49 firmanın Anatolia'da ilanı yayımlandı. Bunlar arasında yayımlanan ilanların sıklıklarına göre bir sıralama yapmak gerekirse; en fazla ilanı yayımlanan firma, 16 reklam ile Holiday Inn'dir. Bunu 10'ar reklam ile EMITT Fuarı, Emek İnşaat ve İşletme A. Ş. ve Makpa izlemektedir. Türkiye İş Bankası'nın sekiz kez reklamı yayımlanırken, Sheraton Ankara ve Halkbank'ın yedişer kez reklamı yayımlandı. Reklamı yayımlanan diğer firmalardan bazılarını belirtecek olursak; Türkiye Kalkınma Bankası altı kez, Meryan Otel, IC Otelleri ve Gloria Golf Resort dörder kez, Öger Tours, Crowne Plaza, ARC Danışmanlık, ORME Jeotermal, Voyager Fua-

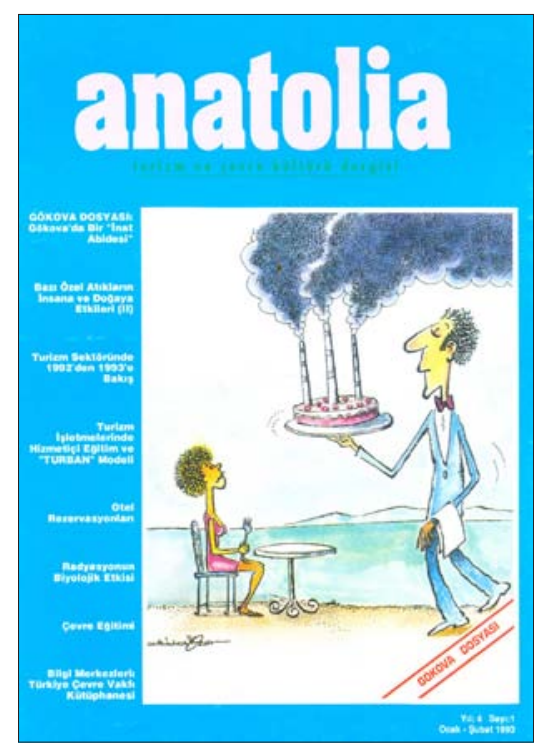

Fotoğraf 4. Ocak - Şubat 1993 sayısı

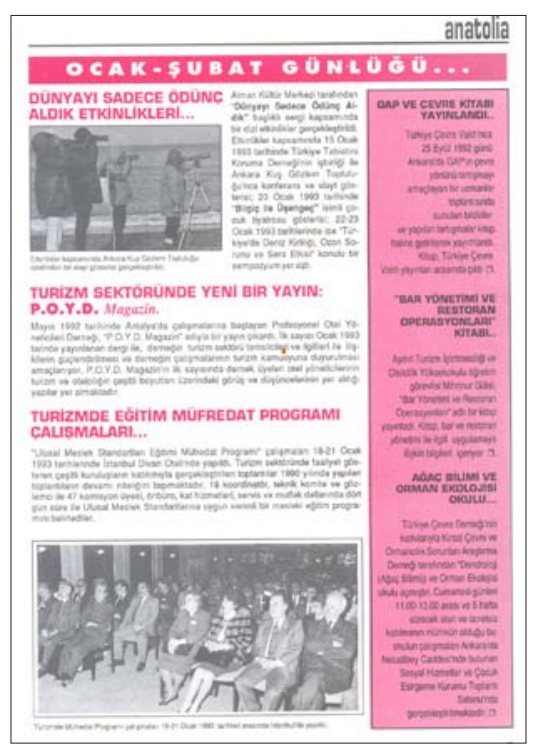

Fotoğraf 5. Turizm haberleri

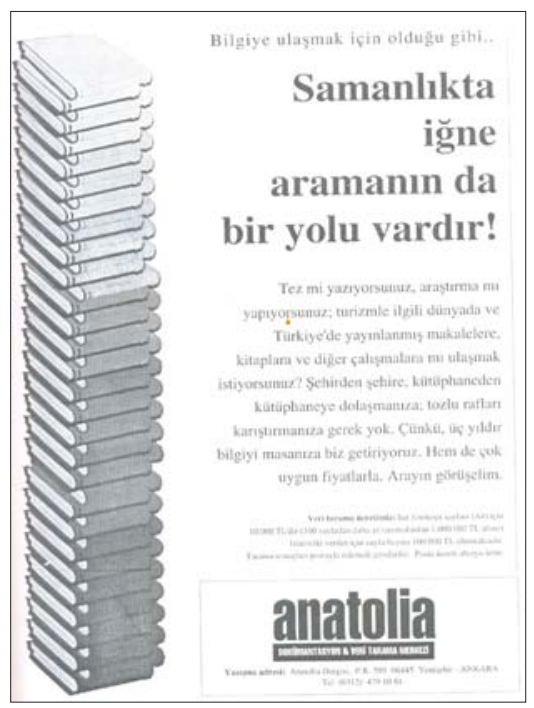

Fotoğraf 6. Anatolia Dokümantasyon ve Veri Tarama Merkezi'nin ilanı 
rı ve Riva Otelleri üçer kez, Panel Eğitim ve Danışmanlık, Kıbrıs Türk Turizm İşletmeleri, Ziraat Bankası, Turban Turizm A. Ş., Efes Pilsen, Hotel Özmen, Aspen Turizm A. Ş., Club Justiniano, Voyager Fuarı, HOTEQ Fuarı, Ortay Turizm İşletmeciliği ve İkbal Termal Otel'in ikişer kez reklamı yayımlandı.

\section{Finansman Sorunları}

Anatolia, 25 yıllık yayın yaşamında sıkça finansman sıkıntıları yaşadı. Enflasyonun çok çok yüksek olduğu, kâğıt ve posta ücretlerine her yıl \%100'ün üzerinde zam yapıldığı göz önüne alınırsa, özellikle 1990'lı yılların zorlu geçtiği anlaşılır. Yaşanan finansman sıkıntıları haliyle derginin çeşitli sayılarında sıkça ifade edildi. İlk olarak finansman sıkıntısının söz edilmesine Ağustos-Eylül 1990 sayısında rastlanıyor. Burada şunlar yazılmış:

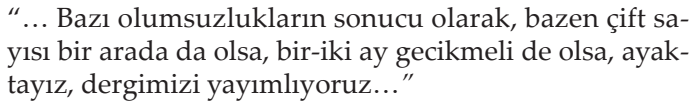

Hemen arkasından yayımlanan Kasım-Aralık 1990 sayısında ülkemizdeki dergilerin finansman sorunlarına değinilmiş:

\begin{abstract}
“... Ve bir yılı tamamladık. Türkiye'de süreli yayınların çoğunluğunun birkaç aylık ömrü olduğu ve Anatolia Dergisi'nin gelir amacına yönelik olmayan, tümüyle amatör bir çalışmanın ürünü olduğu düşünüldüğünde..."
\end{abstract}

İlk sayının üzerinden üç yıl geçtikten sonra, yine bir finansman sorunu...

“Üç yılı aşkın süreden beri çıkardığımız Anatolia Dergisi, çetin koşullara rağmen yaşamsallığını sürdürmektedir. Bu koşullar bizi, dergimizin bazı sayılarını gecikmeli çıkarmaya zorlamakta, ne yazık ki zaman zaman da dergi gecikmeli olarak çıkarılabilmektedir..."

Finansman sorunlarıyla ilgili olarak Dr. Mehmet Özdemir, derginin Eylül 1994 sayısında şunları yazmış:

\footnotetext{
“Türkiye'de bir derginin dört yıl sürekli yayın yapması önemli bir olaydır. Hele bu dergi özel bir konuda yayın yapıyorsa, ticari bir amaç taşımıyorsa ve hele arkasında belirli bir finansman desteği yoksa..."
}

Derginin ilk yedi yılında sıkça finansman sorunlarından söz edilir. Ancak 1997 yılından itibaren finansman sıkıntıları söz konusu olsa da dergide bu konuda artık bir şey yazılmaz. Kanıksanmışlıktan mıdır, yoksa iyi-kötü derginin yayımlanmasından bilinmez, dergi sayfalarında finansman sorunları konusu artık yer almaz.
Anatolia, 2008 yılına kadar alınan ilan gelirleri ile yayımlanır. Ancak, 2008 ve sonraki dönemde dergide hemen hiç ilan yayımlanmaz. Dergi, yürütülen birtakım etkinliklerden elde edilen gelirlerle yayımlanır. Bunlar arasında en büyük payı 2002 yılından itibaren düzenlenen Araştırma Yöntemleri Semineri alır.

\section{TANITIM ÇALIŞMALARI}

Anatolia, ilk dönemlerinden itibaren tanıtım konusuna fazlasiyla önem vermek zorunda kalan bir dergidir. Zira turizmin dinamik ve sürekli gelişim içinde bir alan olması, Anatolia'nın bu dinamik yapıya ayak uydurması zorunluluğunu doğurdu. Derginin ilk sayısından itibaren önce sektöre ve sonrasında akademik çevrelere olmak üzere sürekli olarak tanıtım çalışması yapıldı. Örneğin ilk sayısından 2000 adetin üzerinde basılıp öncelikli olarak turizm işletmelerine gönderdiğimizi anımsiyorum. İlerleyen dönemlerde bu türden postalama çalışmaları hep devam etti. Öte yandan, turizmle ilgili kongrelerde de Anatolia sürekli olarak dağıtıldı. İlk dağıtım 1990 yılında I. Ulusal Turizm Kongresi'nde yapıldı. İzleyen yıllarda düzenlenen pek çok kongrede Anatolia'nın standı kuruldu ve derginin tanıtımı yapıldı.

Postayla veya kongrelerde elden olmak üzere 25 yılda yaklaşık 130 bin derginin dağıtımı yapıldı. Tanıtım çalışmaları 2000'li yıllardan itibaren internetin yaygınlaşmasıyla çevrimiçi olarak da yapılmaya başlandı.

\section{BÖLÜMLERI}

Anatolia ilk sayılarından itibaren hiçbir zaman yalnızca makale yayımlayan bir dergi olmadı. Ne yazık ki günümüzde ülkemizdeki akademik dergilerin çok önemli bir bölümü yalnızca makale yayımlıyorlar. Akademik dergicilik, elbette ki hazırlanan bilimsel çalışmaların sonuçlarının paylaşıldı ̆̆ ortamdır; ancak buna ek olarak akademik dergilerin akademik yaşamı ilgilendiren konularda da bir iletişim ortamı oluşturması beklenir. Anatolia bu amaca yönelik olarak yayımlanan ülkemizdeki ender dergilerden biridir. Zira derginin diğer bölümleri de özenle hazırlaniyor.

Anatolia'dan...: Editöryal içerikte derginin ilk sayısından itibaren yer almaya başlanılan bu yazılarda, dönemin güncel ve akademik konularına yer 
verildi. Uzun dönem Nazmi Kozak tarafından kaleme alınan bölüme 2011 tarihinde son verildi.

Anma: Anma başlıklı bölüm turizm gazetecisi Halük Durukal'ı anmak ve tanıtmak amacıyla Bahar 2003 sayısında yer aldı.

Araştırma Notları: İlki Mart-Haziran 1997 sayısında yayımlandı. Bölümün adı Bahar 2004 sayısında "Araştırma İncelemeleri" adını aldı ve bölümü Dr. Özkan Tütüncü hazırlamaya başladı. Dr. Özkan Tütüncü'nün üstlenmesiyle bölüm sistemli bir şekilde yayımlanmaya başladı. Dr. Tütüncü bölümün adını Bahar 2012 sayısından itibaren "Rekreasyon Incelemeleri" olarak değiştirdi, halen de aynı başlık altında hazırlanıyor.

Ayın Yorumu: Dr. Mehmet Özdemir tarafından hazırlanan ve ilki Mayıs-Haziran 1993 sayısında yayımlanan bölümde, dönemin turizmle ilgili güncel ve akademik tartışmalarını konu alan yazılar yer aldı. Bölüm, Ocak-Haziran 1994 sayısından itibaren derginin ilk sayfalarında yer almaya başladı. Ayın yorumu yazılarına 2006 yılindan sonra son verildi.

Bilgi Merkezleri: Ülkemizde turizm ve ilgili alanlarında faaliyet gösteren kütüphane ve dokümantasyon merkezi gibi bilgi merkezlerinin tanıtımını amaçlayan bu bölümün ilki Kasım-Aralık 1992'de yayımlandı. Bölümde sırasıyla ENFO Bilgi-Erişim, Türkiye Çevre Vakfı Dokümantasyon Merkezi, TUGEV Dokümantasyon Merkezi ve Turizm Bakanlığı Kütüphanesi'nin tanıtımları yer aldı.

Bize Ulaşan Yayınlar: Turizm alanında yayımlanan kitap, istatistik, dergi, bülten vb. dokümanlardan Nazmi Kozak'ın adresine gönderilenlerin künyesine yer verildiği bölümlerin ilki, Eylül- Aralık 1998 sayısında yayımlandı. Bölümde 45 dokümanın künyesi yer alırken, Eylül-Aralık 1998'de 47, Mart-Haziran 1999 'da 20 ve son olarak da EylülAralık 1999 sayısında 23 eserin künyesine yer verildi.

Dosya: Belirli bir konunun kapsamlı olarak incelenmesi amacıyla hazırlanmaya başlanan bölümde, bir tek dosya yayımlanabildi. "Gökova Dosyası" adı altında hazırlanan inceleme, Ocak-Şubat 1993 sayısında yayımlandı. Bu dosya ayn yıllarda Gazi Üniversitesi'nde hazırlanan bir yüksek lisans tez çalışmasına temel oluşturdu.

Editöre Mektup: İlki Eylül-Aralık 1999'da yayımlanan bölüm, iki sayı yayımlandı.
İngilizce Makale İndeksi: Uluslararası süreli yayınlarda yayımlanan makalelerin Türk turizm araştırmacılarına tanıtılmasının amaçlandığı bölüm, Dr. Dilek Acar tarafından Güz 2003 ile Güz 2007 sayıları arasında hazırlandı. İnternet ortamında bu tür bilgilere erişimin yaygınlaşmasıyla bölümün hazırlanmasina son verildi

Internette Araştırmalar: İlk bölüm Mart-Haziran 1998 sayısında yer aldı. Bölümde turizm araştırmac1larının yararlanabileceği internet kaynaklarının tanıtılması amaçlandı. Daha sonra Bahar 2002 ve Bahar 2003 sayılarında Dr. Özkan Tütüncü tarafından iki bölüm hazırlandı.

Kısa Kısa...: Akademik Turizm Bülteni'nin provası niteliğinde olan "Kısa Kısa" başlıklı bölümlerinin ilki Eylül-Ekim 1992 sayısında yayımlandı. Sonraki sayılarda bölümün adı, derginin yayımlandığı sayının ay adını alarak devam etti. Bu bölümün son örneği Mart-Haziran 1996 sayısında yayımlandı.

Konferans Notlar: Dergideki en eski bölümlerden biridir. İlk konferans notu Eylül-Aralık 1990 say1sinda "Mersin'de, İçel ve Turizmi Konulu Panel" adıyla yayımlandı. Sonraki yıllarda konferans notları bölümü yer almaya devam etti. Ancak, bu bölümün sistemli bir şekilde hazırlanması, bölüm editörlügünü Dr. Murat Azaltun'un üstlenmesiyle gerçekleşti. Dr. Azaltun'un bölüm editörlüğünü üstlendiği 2000 yılından itibaren bölümde yer alan yazı sayısı sürekli artış gösterdi. Dr. Azaltun'un bölüm editörlüğü döneminde (2000-2014) toplam 117 konferans notu yayımland.

Konferans Takvimi: İlki Mart-Haziran 1998 say1sında yayımlandı. Ülkemizde düzenlenen akademik toplantıların duyurulmasını amaçlayan bölüm Mart-Haziran 2000 sayısından sonra yayımlanmadı.

Makale İncelemeleri: Yalnızca bir sayı yayımlandı. Mart-Haziran 1999 sayısında bir makalenin tanıt1mi yapild1.

Makale İndeksi: Ülkemizdeki süreli yayınlarda yayımlanan makalelerin turizm araştırmacılarına duyurulmasını amaçlayan bölümün ilki Bahar 2001'de yayımlandı. İlk iki bölüm Medat Yolal tarafından hazırlandı. Bölüm, Bahar 2004 ile Bahar 2007 arasinda Dr. Ozan Aksöz, Güz 2007 ile Güz 2009 arası Dr. Çağıl Hale Özel tarafından hazırlandı. Bölüm Güz 2009 sayısından itibaren Dr. Deniz Karagöz tarafından hazırlanıyor. 
Makaleler: Anatolia'nın 25 yıllık yayın yaşamında makale içeriğinde toplam 510 eser yayımlandı. Buna ek olarak dergide yayımlanan çeviri makalelerin sayısı ise $33^{\prime}$ tür. Telif ve çeviri olmak üzere yayımlanan toplam makale sayısı 543'tür. Yayımlanan makale sayıları ilk yıllarda yüksek rakamlarda iken özellikle 2001 yılından itibaren bir ciltte yayımlanan makale sayısı 10-17 arasında değişmeye başladı, özel sayılar bir yana bırakılırsa bu rakam 13-14 makale üzerinde yoğunlaştı. Yayımlanan makalelerin 277'si derginin hakem-denetimsiz yayımlandığ 1 döneme ait iken hakem-denetimli dönemde (1998-2014) 233 makale yayımland1.

Okuyucu Mektupları: İlk ve son kez Ekim-Kasım 1990 sayısında dergiye gönderilen bir mektup yayımland1.

Özel sayılar: Anatolia'da toplam dört özel sayı yayımlandi. Bunlardan ikisi konulu ve diğeri ikisi de kişiye özel sayılardır. İlk özel sayı Mayıs-Haziran 1991'de "Termal Turizm" başlığı altında yayımlandı ve bu özel sayıda toplam 9 makale yer aldı. Seçilen özel sayıların konuları dönemine göre yeni alanlar olup, örneğin termal turizm konulu özel sayı, derli toplu olmasıyla alanında ender bir yayındır. İkinci özel sayı Mart-Nisan 1992 sayısında "Dış Tanıtım ve Turizm" konusunda yayımlandı. Bu özel sayıda toplam 6 makale yayımlandı. Anatolia'da yayımlanan kişiye özel özel sayılardan ilki Prof. Dr. Hasan Olalı adına hazırlandı. Eylül-Aralık 2001 sayısında hazırlanan bu özel sayıda toplam 17 makale yayımland1. Diğer özel sayı ise Prof. Dr. Hasan Işın Dener adına hazırlandı. Bahar 2010 sayısında yayımlanan özel sayıda 14 makaleye yer verildi.

Seçme Çeviri Makaleler: Bölüm ilk olarak Bahar 2005 sayısında yayımlanmaya başlandı. Bahar 2005 ile Güz 2009 arasında kalan sayılarda "Seçme Çeviri Makaleler" bölümünün editörlüğü Dr. Teoman Duman tarafından yerine getirildi. Bölüm editörlüğü görevini Güz 2010’da Dr. Deniz Küçükusta üstlendi. Bölüm halen Dr. Küçükusta tarafından hazirlaniyor.

Sektörden: Derginin sektör ile turizm akademiası arasında köprü olmaya yönelik yayın politikasının ağır bastığı dönemlerde yayımlanan bir yazı dizisidir. Bir sayfa olarak hazırlanan yazılar Abdullah Tekin, Tankut Ünal, Mehmet Özdemir ve Hüsnü Gümüş tarafından kaleme alındı.

Söyleşiler: Derginin ilk iki yılında "söyleşi" türünde yazılara da yer verildi. Yukarıda da açıklandığı üzere derginin sektör ile akademia arasında köprü olma düşüncesinin bir ürünü olan bu söyleşiler, bir anlamda "sözlü tarih görüşmesi" içeriğinde, akademik yönü ağır basan çalışmalardır. 1990-1992 yılları arasında toplam 13 söyleşi dergide yayımland. Gerçekleştirilen görüşmelerin konuları ve seçilen kişiler incelendiğinde, günümüzün turizm araştırmacılarının da yararlanabileceği söyleşiler

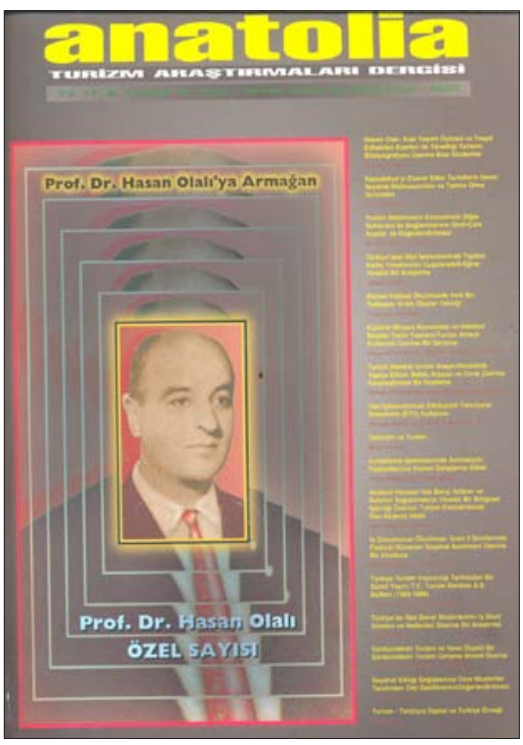

Fotoğraf 7. Prof. Dr. Hasan Olalı Özel Say1s1

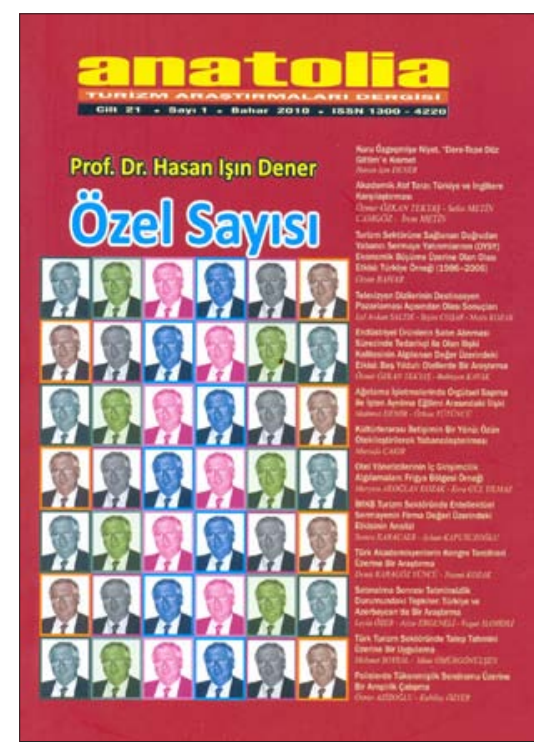

Fotoğraf 8. Prof. Dr. Hasan Işın Dener Özel Sayısı

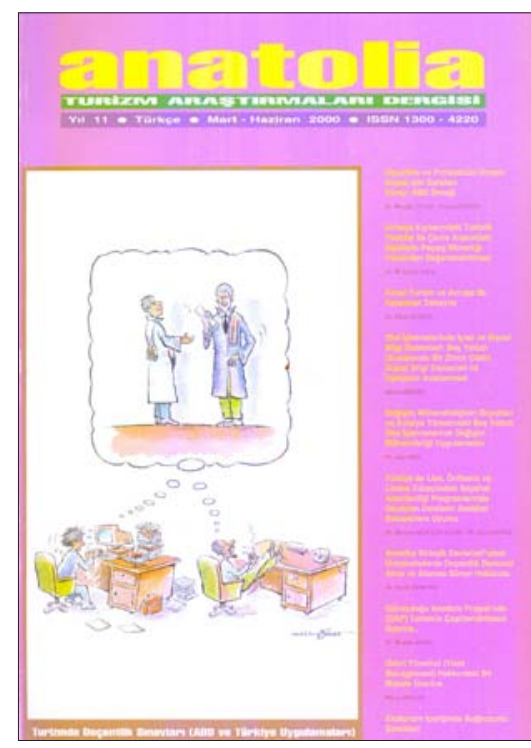

Fotoğraf 9. Anatolia'nın bir kapak sayfası (Çizen: Prof. Atila Özer) 
olduğu görülür. Görüşme yapılan kişiler şu şekilde sıralaniyor: Mustafa Türkmen (Turizm Bakanlığ1 Müsteşarı), Dr. Mehmet Özdemir (Turban Turizm A. Ş. Genel Müdürü), Prof. Dr. Doğan Tuncer (Akademisyen), Beylan Öz (Anadolu Turistik İşletmeciler ve Otelciler Derneği Başkanı), Bahattin Yücel (TÜRSAB Başkanı), Saffet Yatağan (Turizm İşletmecisi), Prof. Dr. Turgut Var (Akademisyen), Mukadder Sezgin (Turizm Bakanlığı Eski Müsteşarı), Özgen Acar (Gazeteci), Engin Ural (Türkiye Çevre Vakfı Başkanı), Doç. Dr. Muzaffer Evirgen (Akademisyen), Başaran Ulusoy (TÜRSAB Başkanı) ve Abdülkadir Ateş (Turizm Bakanı).

Tez Özetleri: İlki 1995'te hazırlanmaya başlanan bir bölümdür. 1995-2000 yılları arasında toplam 83 tez özeti yayımlandı. Tez özetleri bölümü sistemli bir şekilde Dr. Hatice Güçlü Nergiz ile birlikte (Bahar 2006) hazırlanmaya başlandı. Günümüze kadar geçen sürede toplam 261 tez özeti Dr. Güçlü Nergiz tarafından yayıma hazırlandı.

Turizm Araştırma İncelemeleri: İlk bölümü Güz 2013 sayısında yayımlandı. Dr. Çağıl Hale Özel tarafından hazırlanan bölümün amacı, turizm alanında hazırlanan araştırmaların tanıtılmasıdır.

Turizm Notları: İlki Eylül-Aralık 1999'da yayımlanan bölüm, derginin iki sayısında yer aldı.

Türk Turizm Tarihinden: Bölüm ilk olarak Dr. Mehmet Özdemir tarafından Bahar 2011 sayısında hazırlanmaya başlandı. Dr. Özdemir tarafından halen hazırlanmaya devam edilen bölümde Türk turizm tarihinde gizli kalmış olaylar ve kişilerin yeni kuşaklara tanıtılması amaçlanıyor.

Ulusal Turizm Dergileri: Mart-Haziran 2000 say1sında iki akademik turizm dergisinin tanıtımı yapıldı.

Uluslararası Turizm Dergileri: İlki Eylül-Aralık 1998 sayısında hazırlanan bölüm dört sayı yayımlandı. Bu dönemde uluslararası alanda yayımlanan toplam 14 akademik turizm dergisinin tanıtımını içeren yazılar yayımlandı. Yazılar, bu satırların yazarının yürüttüğü bir araştırma kapsamında derlediği anketlerdeki bilgilerden yararlanılarak hazırlandi.

Yeni Yayınlar: İlki Mart-Haziran 1997'de yayımlandi, daha sonra Mart-Haziran 1998 sayısıyla sona erdi. Bölümde turizm alanında yayımlanan yeni kitapların tanitımı yapildı.

\section{YAZARLAR}

Anatolia, 25 yıllık yayım yaşamında ülkemizdeki akademisyen, lisansüstü öğrenci, araştırmacı, bürokrat ve sektör mensubu olmak üzere geniş bir kesimin yazılarını yayımladığı bir dergi oldu. Derginin hakem-denetimsiz yayımlandığı dönemler ile hakem-denetimli yayımlandığı dönemlerin yazarları biribirinden ayrılıyor. 1997 yılı öncesi dönemlerde çok çeşitli çevrelerden yazarların yazıları yayımlanırken derginin hakem-denetimli yayımlanmaya başladığ 1998 yılından sonra yazarların tamamına yakını akademik çevrelerden oldu.

Akademisyen yazarlar incelendiğinde, 2003 yılı öncesinde, neredeyse bütün Türk akademisyenlerden her birinin en az bir yazısının Anatolia'da yayımlandığı görülür.

\section{YAYIM UYGULAMALARI}

Bu bölümde Anatolia'nın yayım uygulamaları hakkında bilgiler yer alıyor. Derginin 25 yıllık yayım yaşamında pek çok yayım uygulaması yaşama geçmiştir. Anatolia, pek çok uygulaması ile diğer akademik çalışma dallarındaki dergilere öncü ve örnek olacak bölümlere yer verdi.

Indeks hazırlama: Dergide yayımlanan yazıların indeksinin hazırlanmasına ilk kez Ocak-Haziran 1994 sayısında, derginin ilk beş yıllık döneminin yayın indeksinin hazırlanması ile başlandı. İkinci indeks çalışması "Anatolia Dergisi Bibliyografyası (1990-1995)" başlığı altında Eylül-Aralık 1995 sayısinda yayımlandı. Sonraki yıllarda da yayın indeksi yayımina devam edildi. Mart-Haziran 1997 sayısında "1995-1996 Yayın Dizini" ve Mart-Haziran 1998 sayısında ise "1997 Yayın Dizini" başlıklı dizinler hazırland1. Bu tarihten sonra her yılın sonunda yayın dizini hazırlama çalışması periyodik olarak hazırlanmakta ve yayımlanmaktadır. Öte yandan, son kapsamlı yayın indeksi Eylül-Aralık 1999 sayısında "Yazar İndeksi (1990-1999)" başlığı altında yayımlandi.

İnternetin kullanımı: Özellikle 2000 y1lından sonra ülkemizde internet yoğun bir şekilde kullanılmaya başland1. Anatolia'da internetin getirdiği olanaklardan yararlanabilmek için web sayfası oluşturma çabası ilk kez, o dönemde ABD'de doktora öğrencisi olan Cihan Çobanoğlu'nun girişimleri ile başlatıldı. Cihan Çobanoğlu tarafından hazırlanan web sayfası Tripod üzerinden geçici bir adreste yayıma baş- 
ladı. Bahar 2001 sayısından itibaren dergi kendine ait, bugün de geçerli olan bir web adresi ile sayfasına sahip oldu. Halen kullanılmakta olan web sayfası 2010 yılında oluşturuldu ve dergide yayımlanan yazı ve makaleler online ortamda açı erişimli hale getirildi.

Öz/özet: Yayımlanan makalelere Türkçe ve İngilizce öz/özet hazırlanması uygulamasına ilk olarak Ağustos-Eylül 1990 sayısında İngilizce öz'e yer verilmesi şeklinde başlandı. O dönemde, Anadolu Üniversitesi öğretim üyesi olan Dr. Uğur Demiray'ın dergide yayımlanan makalelerin Leisure, Recreation and Tourism Abstract'ta (LRTA) yer alması için yaptığı öneriler ve bağlantılar doğrultusunda bu uygulama başlatıldı. Uygulama doğrultusunda 1990 yılının sonundan itibaren dergide yayımlanan pek çok makale LRTA'da yer almaya başladı. Makalelerin özlerinin LRTA'da yer alması uygulamasına, uluslararası Anatolia' nin 1997 yılında yayımlanmaya başlaması ve her iki derginin isim benzerliği dolayısıyla son verildi. Dergide yayımlanan makalelere yalnızca Türkçe öz hazırlanmaya başlandı. Bahar 2005 sayısıyla birlikte derginin TÜBİTAK-ULAKBIM Sosyal Bilimler Veri Tabanı'nda yer almaya başlanmasıyla birlikte yeniden Türkçe ve İngilizce öz hazırlanmasına başlandı. Halen bu uygulama devam etmektedir.

Türkçe yazım/dil denetimi: Derginin ilk sayılarından itibaren editör tarafından yapılan yazım/dil denetimi, 2012 yılından itibaren Dil Editörü Aysel Yılmaz tarafından yerine getirilmeye başlanmıştır. Böylelikle, dergide hakem-denetimden geçen makaleler yayım öncesi yazım/dil editörü tarafından ayrıca incelenmektedir.

Yayın kurulu: İlk yayın kurulu derginin hakem-denetimli yayımlanmaya başlaması ile birlikte oluşturuldu. Makale değerlendirme işlevinin daha nesnel yapılabilmesi için yayın kurulu üyelerinde bazı yıllarda değişikliğe gidildi. 1997 yılında oluşturulan ilk yayın kurulunda 36 üye yer alırken, zaman içerisinde bu sayıda artışlar oldu; yayın kurulu üyesi sayısı 1998'de 46, Eylül-Aralık 2000'de 56, Bahar 2001 'de 60 üyeye çıkt. Bahar 2006'da yayın kurulu üye sayısı 48 'e indirildi, Güz 2009 'da ise 52'ye yükseltildi. Bahar 2011'de 68'e çıkan yayın kurulu üyesi sayısı Güz 2013 sayısında 84 üyeye ulaştı.

Yazım kuralları: Dergiye yazı göndermede uyulması gereken kurallarla ilgili ilk açıklamaya Ağus-
tos-Eylül 1990 sayısında yer verildi. Buradaki açıklamalar, uyulması gereken atıf ve kaynakça düzenine ilişkindi. İlerleyen dönemlerde yazım kuralları biraz genişletildi, örneğin Ocak-Şubat 1991 sayısında makale yazımına ilişkin bazı ek kurallara yer verildi. Yazım kuralları 1997 yılına kadar bir sayfalık açıklamalar şeklinde yer alırken, derginin hakem-denetimli olarak yayımlanmasiyla birlikte açıklamalar iki sayfadan oluşan daha kapsamlı hale getirildi. Yazım kuralları son olarak Güz 2003'te halen kullanılan içeriğine kavuştu.

Yer aldığı veri tabanları: Anatolia, yukarıda da değinildiği üzere, 1990 yılının sonundan itibaren Leisure, Recreation and Tourism Abstract'ta taranmaya başlandı. 1997 yılından itibaren uluslararası Anatolia' nın yayımlanmaya başlanmasıyla LTRA'nın taramasından tek taraflı olarak ayrıldı. 2005 yllından itibaren ise TÜBİTAK-ULAKBIM Sosyal Bilimler Veri Tabanı tarafından taranan dergiler arasına girdi. Geçtiğimiz yıllar içerisinde ise EBSCO, LTRA CAB Abstracts ve Global Health Databeses gibi veri tabanlarının israrlı istekleri sonucu Anatolia bu veri tabanları tarafından taranmaya başland.

\section{DÖNEMLERI}

Anatolia'nın 25 yıllık yayın yaşamı, hakem-denetimli ve hakem-denetimsiz dönemler olmak üzere ikiye ayrılır. Birinci dönem 1990-1997 yıllarını kapsarken, ikinci dönem 1998-2014 yıllarını içerir.

Birinci dönem (1990-1997) kendi arasında iki alt döneme ayrılabilir. Bunlardan ilki, 1990-1994 dönemidir ve bu dönemin karakteristik özelliği derginin kendini kabul ettirme, yayın politikasının yerleşmesi, derginin yönünü bulması, kısacası derginin konumuna kavuşmasıdır. Bu dönemin ilk üç yılı derginin arayışları ile geçmiştir. 1993 ve 1994 derginin yolunu bulmaya başladığı yıllardır.

İkinci dönem de (1998-2014) kendi arasında iki alt döneme ayrılabilir. Bunlardan ilki 1998-2002 yılları arasıdır. Bu dönemin karakteristik özelliği, Anatolia' nın hakem-denetimli yayımlanmaya başlaması ve hakem-denetimli dergi uygulamalarının yerleşmeye başlamasıdır. Hakem-denetimli dergi olma özelliği, hem editöryal hem de yazarlar açısından iki türlü gelişime sahne olmuş, turizmle ilgili makale hazırlayanların hakem-denetimli dergiciliği bütünüyle benimsemeleri beş yıl almış- 
tır. 2003-2014 yılları arası, derginin uygulamalar1nın her yönüyle yerleşmeye, derginin ortaya koyduğu girişimlerle Türk turizm literatürünün ve araştırmalarının şekillenmesinde önemli rol oynamaya başladığı bir dönemdir. 2003 yılı sonrası ise Anatolia'nın bir dergiden öte işlevler üstlendiği yıllardir.

\section{GİRişiMLERI}

Anatolia, bu yazının başlı̆̆ında da vurgulanmak istendiği üzere, bir dergi olarak yayın yaşamına başlamış olmasına karşılık, özellikle 2000 yılı sonrasında gerçekleştirdiği etkinlikler ile farklı bir konuma ulaşmıştır. Aşağıda dergi tarafından gerçekleştirilen etkinliklerin kısa açıklamaları yer alıyor.

Anatolia DokümantasyonEVeri Tarama Merkezi: Turizm alanında tez ve araştırma yapanlara yönelik kaynak taraması yapmak ve elde edilen kaynakların fotokopilerinin temin edilmesi amacıyla oluşturuldu. 1992-1996 yılları arasında faaliyet gösteren Merkez bünyesinde 50'nin üzerinde araştırmacıya hizmet sunuldu. Merkez'in faaliyetlerine 1995 yılı bitiminde son verildi.

Anatolia Turizm Yayınları Merkezi: 1990'1 yıllarda yayımlanmış turizmle ilgili başta ders kitapları olmak üzere posta ile satış yapmak üzere oluşturuldu. Hazırlanan ve bastırılan yayın katalogları ile tanıtımı yapılan kitaplar, sipariş edenlere ödeme- li posta şeklinde gönderildi. 1992-1993 yılları arasinda faaliyet gösteren Merkez'de 100'ün üzerinde farklı turizm kitabının satışı yapıldı. Merkez'in satışını yaptığ talogları ile Anatolia Dergisi'nin çeşitli sayılarında (örneğin Ocak-Şubat 1993 sayısında 53 kitap; MartNisan 1993 sayısında 63 kitap; Mayıs-Haziran 1993 sayısında 64 kitap, Kasım-Aralık 1993 sayısında 32 kitabın listesi) yer aldı. Merkez, 1993 yılından itibaren Anatolia Yayıncllı unvanı altında faaliyetlerini sürdürdü.

Anatolia Yayıncılık: Turizm alanında ders kitabı yayımlamak üzere kuruldu. Anatolia Yayıncılık'ın yayınladığı ilk kitap, halen de yayımlanmakta olan Meryem Akoğlan'a ait "Otel İşletmelerinde Kat Hizmetleri Yönetimi"dir. Bu kitap 1993 yılında yayımland1. Ardından "Genel Turizm: Ilkeler-Kavramlar" (Nazmi Kozak, Metin Kozak, Meryem Akoğlan) kitabı (1994) yayımlandı. 1995 yılının sonunda ise "Otel İşletmeciliği" (Editör: Nazmi Kozak), "Seyahat Acentacılı̆̆ ve Tur Operatörlüğü" (Orhan İçöz), "Turizm Pazarlaması" (Orhan İçöz), "Türkiye Turizm Tezleri Bibliyografyası (1952-1995)" (Nazmi Kozak) kitaplarının yayımı tamamlandı. Yayımlanan ders kitaplarının biri hariç ("Otel İşletmeciliği” kitabının bu satırların yazarının isteği ile birkaç baskıdan sonra yeni yeni baskıları yapılmadı.) diğerleri halen piyasada basımları yapılan kitaplardır. Bunlardan "Genel Turizm: İlkeler-Kavramlar" adlı kitap

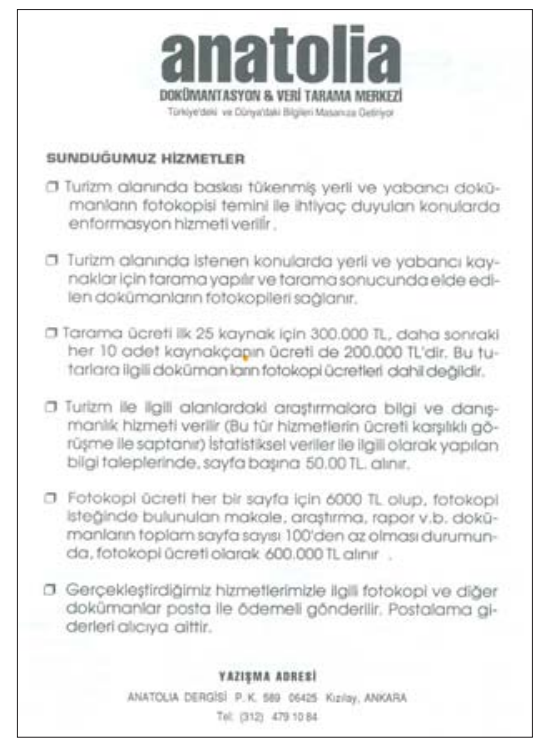

Fotoğraf 10. Anadolu Dokümantasyon ve Veri Tarama Merkezi'nin ilanı

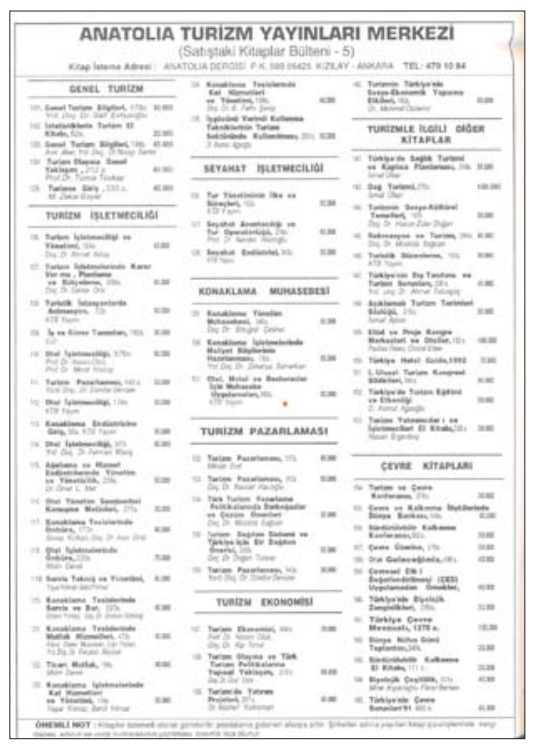

Fotoğraf 11. Anatolia Turizm Yayınları Merkezi'nin ilanı

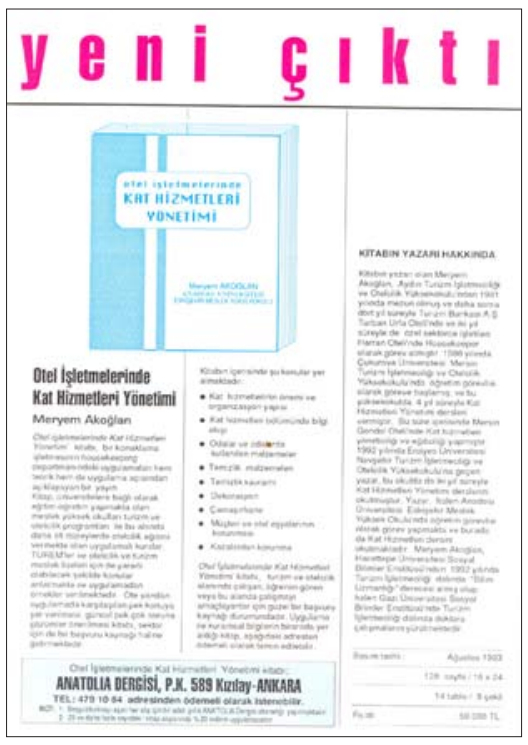

Fotoğraf 12. Anatolia Yayıncılık'ın yayımladığı ilk kitap 
Anatolia: Turizm Araştırmaları Dergisi: Bir Dergiden Öte, Belki de Bir Enstitü...

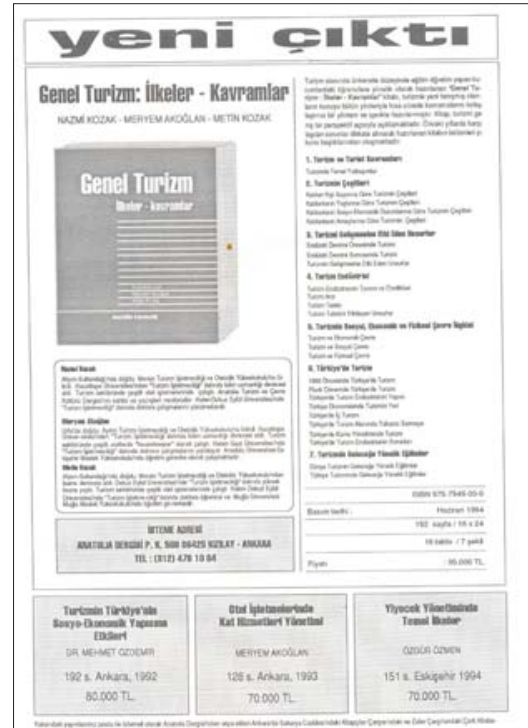

Fotoğraf 13. Anatolia Yayıncılık'ın yayımladığı ikinci Kitap

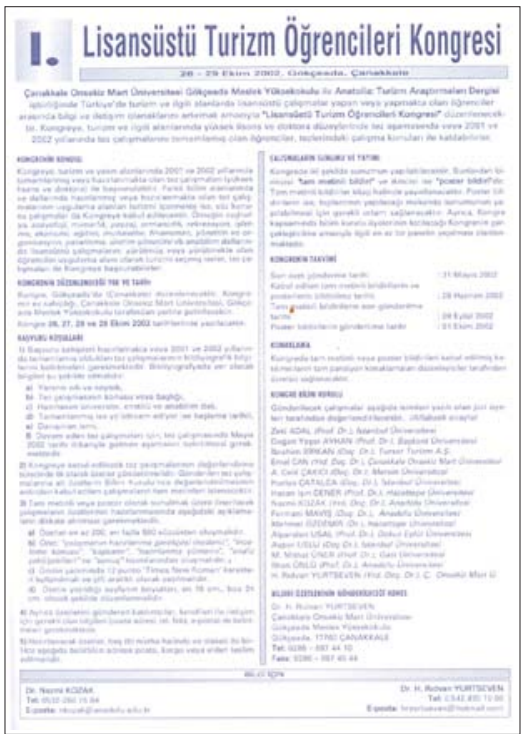

Fotoğraf 14. I. lisansüstü Turizm Öğrencileri Kongre'sinin afişi.

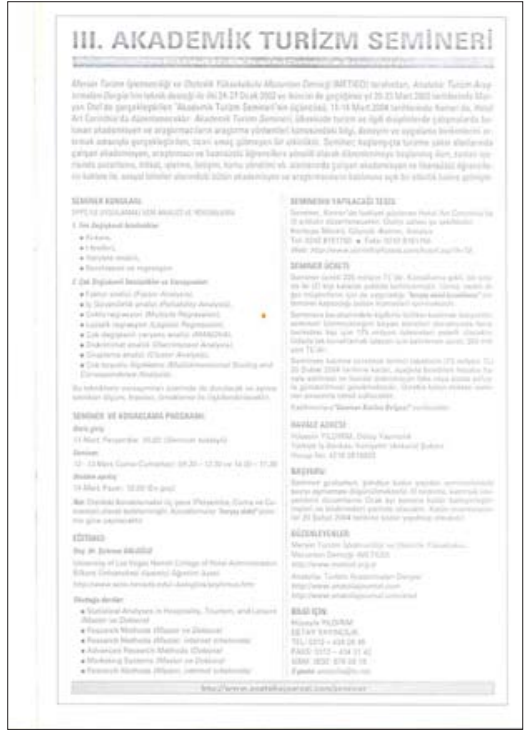

Fotoğraf 15. Araştırma Yöntemleri Semineri'nin afiși. ülkemizde turizm alanındaki hiçbir ders kitabının ulaşamadığı bir rekoru kırarak 15. baskıya ulaştı. Anatolia Yayıncılık'ın yayımlandığı kitaplar, 1996 yılında bu satırların yazarının askerlik görevi dolayisıyla Turhan Kitabevi'ne devredildi ve Anatolia Yayıncılık' in faaliyetlerine son verildi.

Akademik Turizm Bülteni: 1992 yılında başlatılan ve 1996 sonunda son verilen "Kısa Kısa" başlı̆̆ altındaki turizmle ilgili haberlere yer verme uygulamasına, internetin yaygınlaşmasıyla 2000 yılının Eylül ayından itibaren "Akademik Turizm Bülteni" adı altında devam edildi. Bu satırların yazarının Başkent Üniversitesi'nde görevli olduğu dönemde başlatılan ve ilk aylarda 300 dolayında e-posta adresine gönderilen Bülten, şimdilerde 5000 adrese gönderilmekte, yer aldığ 1 haber siteleri ile 50 bin kişinin bilgisine ulaşmaktadır. Akademik Turizm Bülteni, turizm alanındaki haberlerin yanı sıra yeni yayınlar, tamamlanan tez çalışmaları, atama haberleri gibi bölümleri içermekte ve 15 yıldır yayımlanmaktadır.

Akademik Turizm Eğitimi Arama Konferansı: İlki 2009 yılında düzenlenen ve turizmle ilgili akademik konuların arama konferansı yöntemiyle tartışıldığı bir bilimsel etkinliktir. Her yıl düzenli olarak organize edilmeye çalışılan arama konferansları şimdiye kadar beş kez düzenlendi. Konferanslar bir otelin konaklama sponsorluğunda dü- zenlenmekte ve her toplantiya 40-45 akademisyen davet edilmektedir. Arama konferanslarında şimdiye kadar "Lisans Düzeyindeki Turizm Programla$r r^{\prime \prime}$, "Lisansüstü Düzeylerdeki (Yüksek Lisans ve Doktora) Turizm İşletmeciliği Programları", "Disiplin Olarak Turizmin Bilimsel Konumu "Turizm Konulu Akademik Ders Kitapları" ve "Turizm Alanında Doçentlik Sınavları: Disiplinlerarası Bir Alanda Niteliğin ve Başarının Ölçütleri Neler Olmalı?" konuları tartışılmıştır. Arama konferanslarının sonuçları kitap olarak yayımlanmaktadır.

Araştırma Yöntemleri Semineri: 2002 yılında "Akademik Turizm Semineri" adı altında düzenlenmeye başlandı. İlk dönemlerdeki düzenlenme amacı, turizm ve yakın alanlarında görevli akademisyenler ile lisansüstü öğrencilerin araştırma yöntemleri konusundaki bilgi ve deneyim birimini artırmaktı. İlerleyen dönemlerde sosyal bilimlerden gelen akademisyen ve lisansüstü öğrencilerin katılımıyla topluma mal olan bir bilimsel etkinlik haline ulaştı. Temel amacin ticari olmaması ve organizasyon maliyetlerini ancak karşılayan bir gelirle gerçekleştirilmesi, Araştırma Yöntemleri Seminerlerinin 11 yıl aralıksız düzenlenmesine ve toplam 1500 'den fazla kişinin katılmasına yol açtı. Ülkemizde (ve belki de dünyada) bir benzeri olmayan geniş kapsamlı bu bilimsel bir etkinlik Türk bilim tarihinde yerini almıştır. Başlangıçta, bir konu ve bir salon ile başlayan seminerler, son yıllarda 10 farklı konu ve 10 


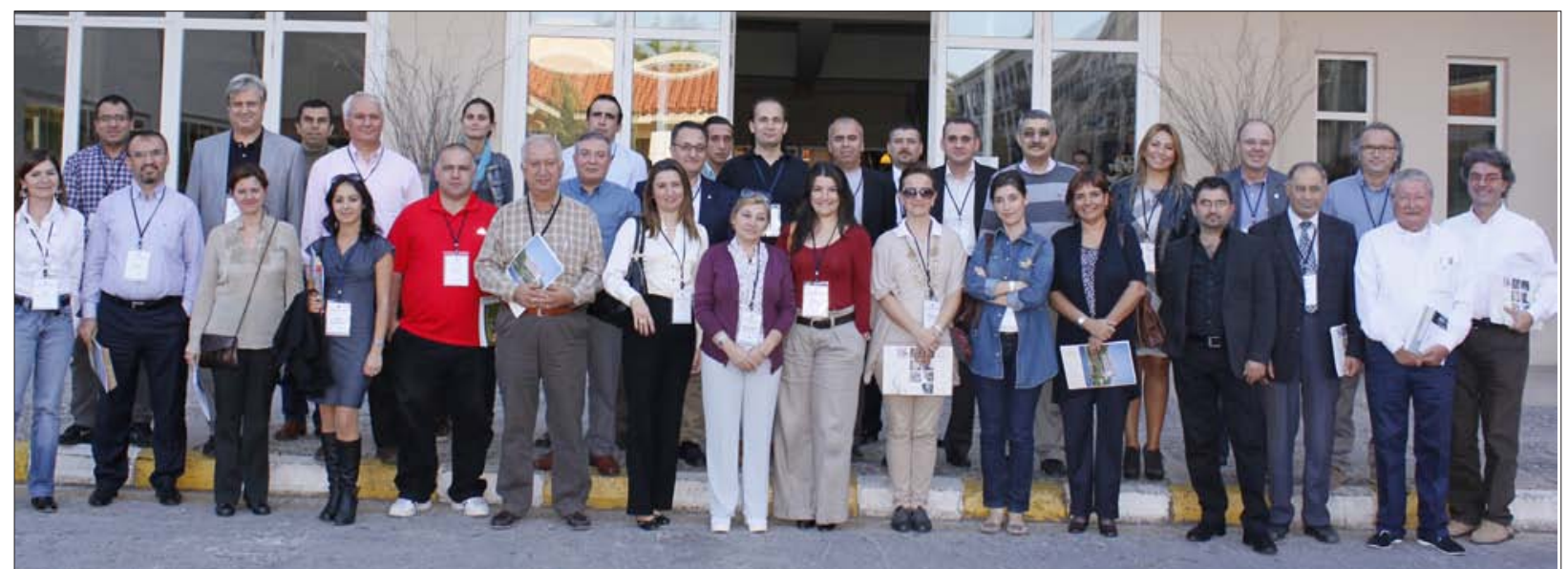

Fotoğraf 16. 4. Akademik Turizm Eğitimi Arama Konferansı'na katılanlar toplu halde (30 Ekim 2011).

ayrı salona kadar yükselen bir trende sahip oldu. Anatolia: Turizm Araştırmaları Dergisi, diğer ortakları değişikliğe uğrasa bile başından beri Araştırma Yöntemleri Seminerleri'nin başat aktörü oldu.

\section{Disiplinlerarası Turizm Araştırmaları Kongresi:} Turizmin disiplinlerası bir alan olmasından hareketle, bu alandaki çalışmaların niteliğini artırmak amaciyla ilk kez 2010 yılında düzenlenmeye başlandı. İlk kongre, Muğla Üniversitesi ile Anatolia: Turizm Araştırmaları Dergisi'nin işbirliğinde Nevşehir'de düzenlendi. 2010 yılında Akdeniz Üniversitesi, 2014 de ise Adnan Menderes Üniversitesi kongrenin ev sahipliğini üstlendiler.
II. Eğirdir Turizm Sempozyumu: Süleyman Demirel Üniversitesi Eğirdir Meslek Yüksekokulu ile Anatolia: Turizm Araştırmaları Kongresi'nin işbirliğinde 2006 yılında Eğirdir'de düzenlendi.

Interdisciplinary Tourism Research Conference: Turizmin disiplinlerarası boyutunu ön plana çıkarmayı amaçlayan uluslararası kongrenin ilki 2010 yılında Nevşehir'de düzenlendi. İkinci kongre 2012'de Fethiye'de gerçekleştirildi. Kongrenin üçüncüsü 2014 yılında İstanbul'da yapılacaktır. Kongre, alanında düzenlenen dünyadaki tek kongredir.

Lisansüstü Turizm Öğrencileri Kongresi: İlk üç kongre 2002, 2004 ve 2006 yıllarında Çanakkale On-

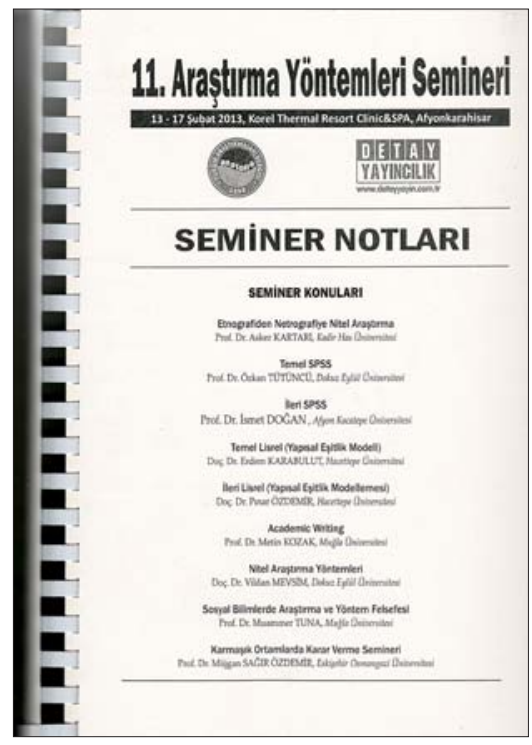

Fotoğraf 17. 1. Araştırma Yöntemleri Semineri notları kitapçı̆̆ 1

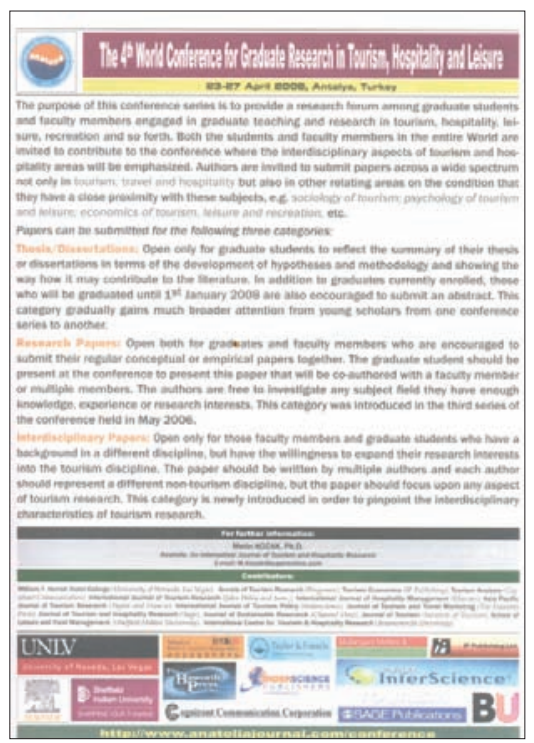

Fotoğraf 18. Uluslararası Turizm Öğrencileri kongresi afişi.

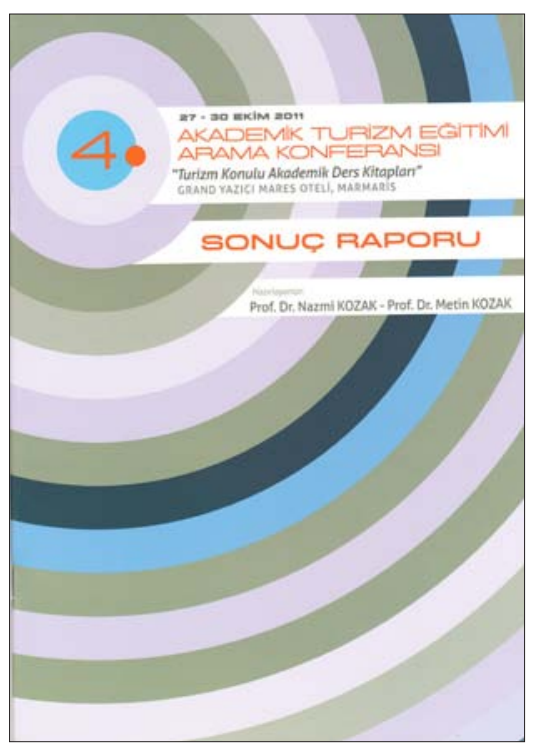

Fotoğraf 19. 4. Akademik Turizm Eğitimi Arama Konferansı Sonuç Raporu kitabı 


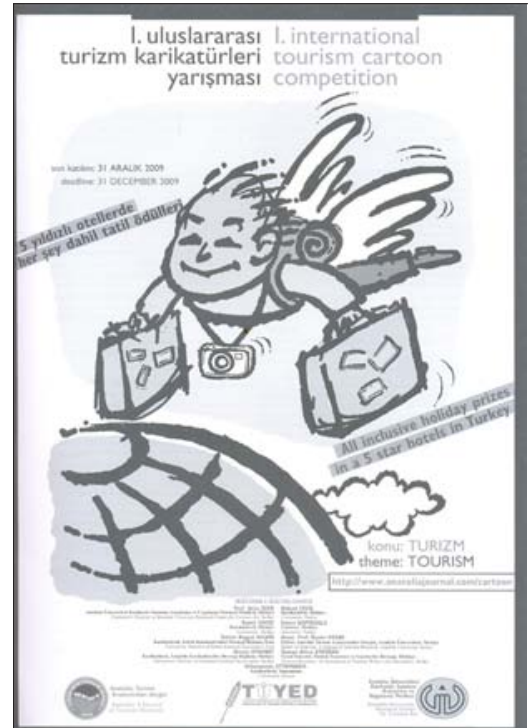

Fotoğraf 20. I. Uluslararası Turizm Karikatürleri Yarışması afişi

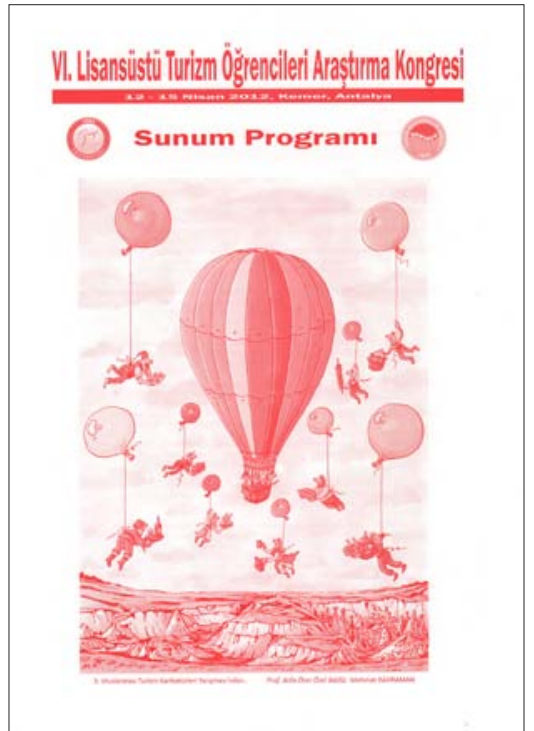

Fotoğraf 21. Kongre krogram kitapçı̆̆1

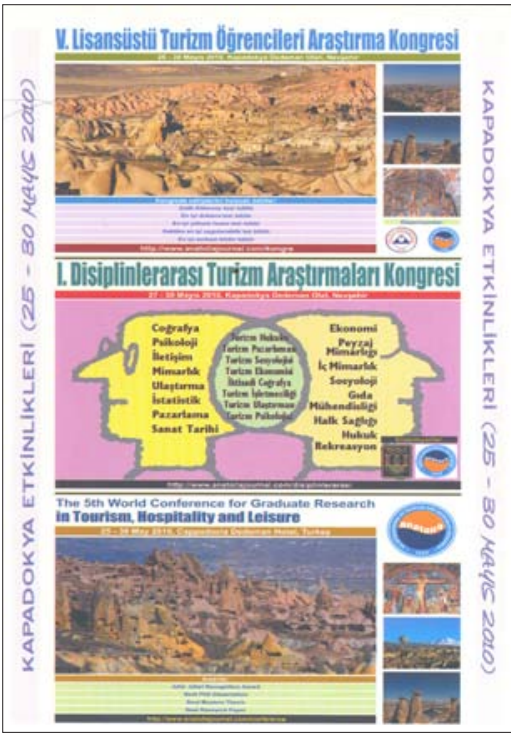

Fotoğraf 22. Anatolia Turizm Kongreleri afişi (Derginin arka kapağında) sekiz Mart Üniversitesi Gökçeada Meslek Yüksekokulu ile Anatolia: Turizm Araştırmaları Dergisi'nin işbirliğinde düzenlendi. 2008 yılından itibaren kongrenin adı "Lisansüstü Turizm Öğrencileri Araştırma Kongresi" şeklinde değiştirildi ve her iki yılda farklı bir üniversitenin ev sahipliğinde düzenlenmeye başlandı. 2008 yılında İstanbul Teknik Üniversitesi, 2010 yılında Erciyes Üniversitesi, 2012'de Gazi Üniversitesi ve 2014 yılında ise Dokuz Eylül Üniversitesi'nin ev sahipliğinde düzenlendi. Kong- re, "lisansüstü tezler" ve "araştırma bildirileri" olmak üzere iki bölümden oluşmaktadır. Kongreyi özgün kılan yönlerden biri de kongrede seçici kurulların sunulan tez çalışmalarını ve bildirileri sunumları sırasında izleyerek, ödüllendirilecek tez çalışmalarını ve bildirileri seçmeleridir.

Rekreasyon Araştırmaları Kongresi: Ülkemizde yeni bir dal olan rekreasyon alanının gelişimine olumlu yönde etkide bulunabilmek amacı ile 2012 yılından itibaren Rekreasyon Araştırmaları Kong-

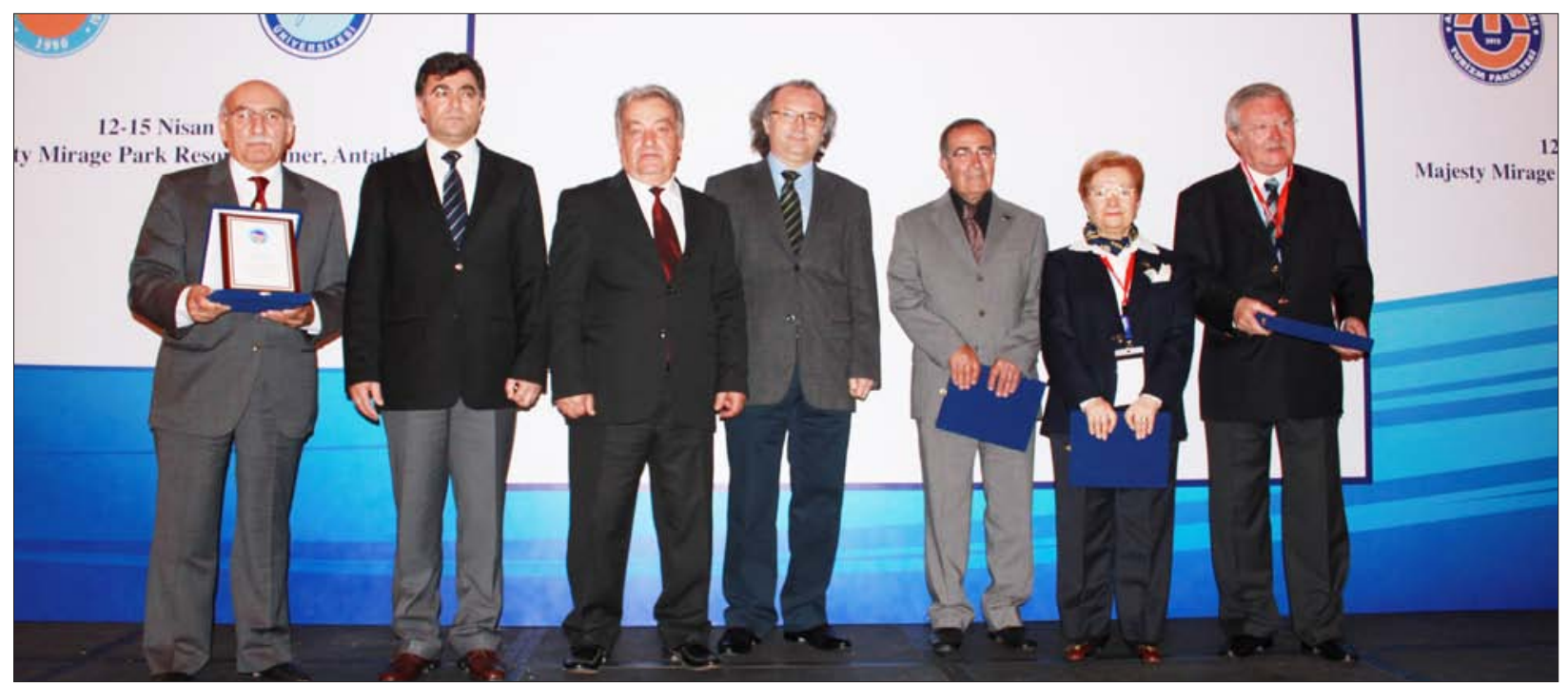

Fotoğraf 23. Turizm Hizmet Ödülleri Töreni (Ödül alanlar toplu halde), 14 Nisan 2012, Kemer, Antalya. (Soldan sağa: Avni Aker, Antalya Vali Yardımcısı, Akdeniz Üniversitesi Rektör Yardımcısı, Prof. Dr. Nazmi Kozak, Abdullah Tekin, Gülsen Kahraman, Dr. Mehmet Özdemir) 


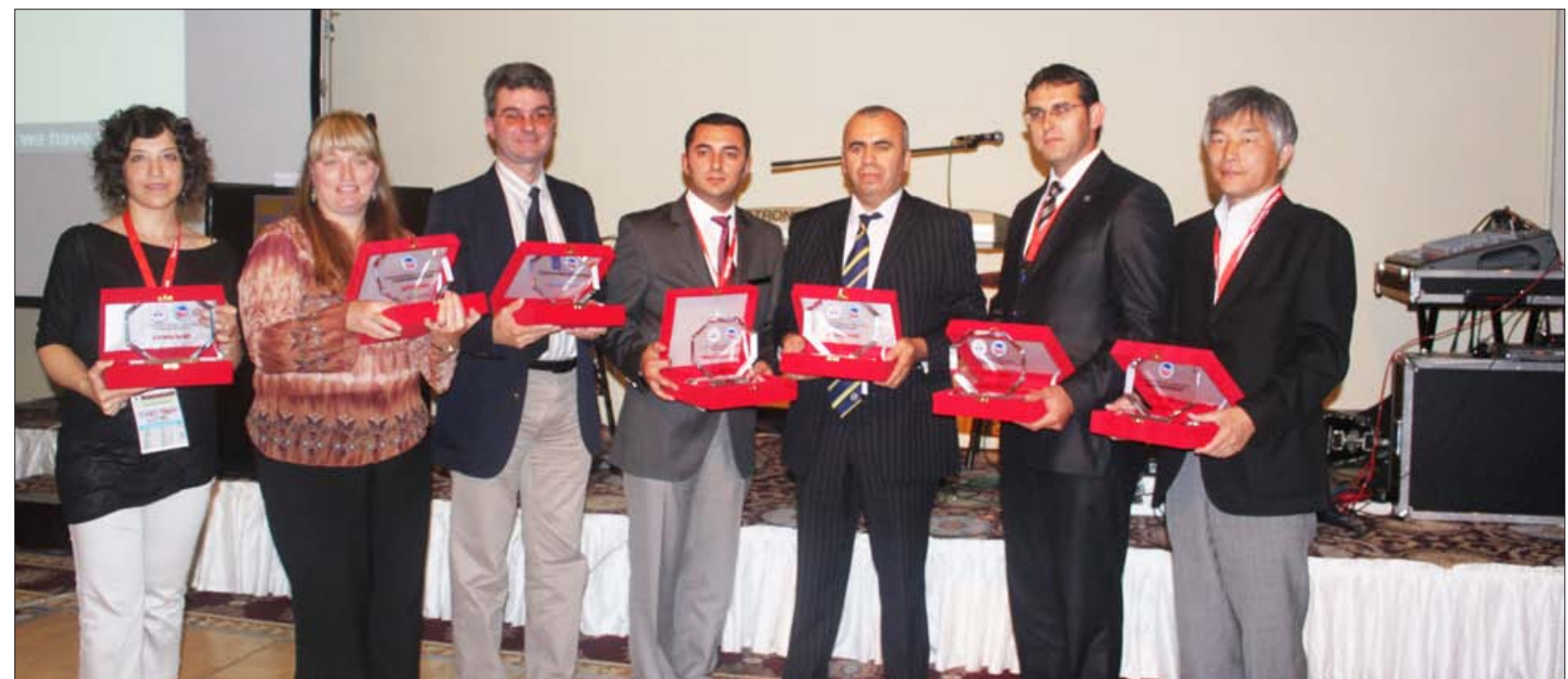

Fotoğraf 24. V. Lisansüstü Turizm Öğrencileri Araştırma Kongresi, I. Disiplinlerarası Turizm Araştırmaları Kongresi ve 5th World Conference for Graduate Research in Tourism Hospitality and Leisure'de ödül alanlar (29 Mayıs 2010). (Soldan sağa: Dr. Çağıl Hale Özel, La Vergne, Dr. Özkan Tütüncü, Harun Çalhan, Dr. Mahmut Demir, Mune Kitajima.

resi düzenlenmeye başlandı. İlk (2012) ve ikinci (2013) kongrenin ev sahipliğini Dokuz Eylül Üniversitesi yerine getirdi. Anatolia: Turizm Araştırmaları Dergisi, artan iş yükü dolayısıyla 2013 yılındaki ikinci kongreden sonra bu kongrenin düzenlenmesinden çekildi.

Turizm Eğitimine Hizmet Ödülleri: Turizm araştırmaları ile eğitimine katkıları olan ve emekli olmuş veya yakın dönemde emekli olacak kişilere Anatolia: Turizm Araştırmaları Dergisi tarafından teşekkür içeriğinde plaket verilmektedir. Törenler, 2008 yılından bu yana Lisansüstü Turizm Öğrencileri
Araştırma Kongresi kapsamında düzenlenmektedir. Şimdiye kadar; Prof. Dr. Turgut Var, Prof. Dr. Meral Korzay, Boğaziçi Üniversitesi, Prof. Dr. Cemil Boyac1, Prof. Dr. Alparslan Usal, Prof. Dr. Kubilay Baysal, Yrd. Doç. Dr. Şule Cetın, Alev Alatlı, Dr. Özen Dallı, Fehmi Köfteoğlu, Dr. Orhan Mesut Sezgin, Şaban Ali Yaşaroğlu, Hüseyin Yıldırım, Dr. Mehmet Özdemir, Avni Aker, Gülsen Kahraman ve Abdullah Tekin'e teşekkür plaketi verildi.

TUYED-Anatolia Turizm Seminerleri: Turizm Yazarları ve Gazetecileri Derneği ile Anatolia: Turizm Araştırmaları Dergisi'nin işbirliğinde 2007-2008 yıl-

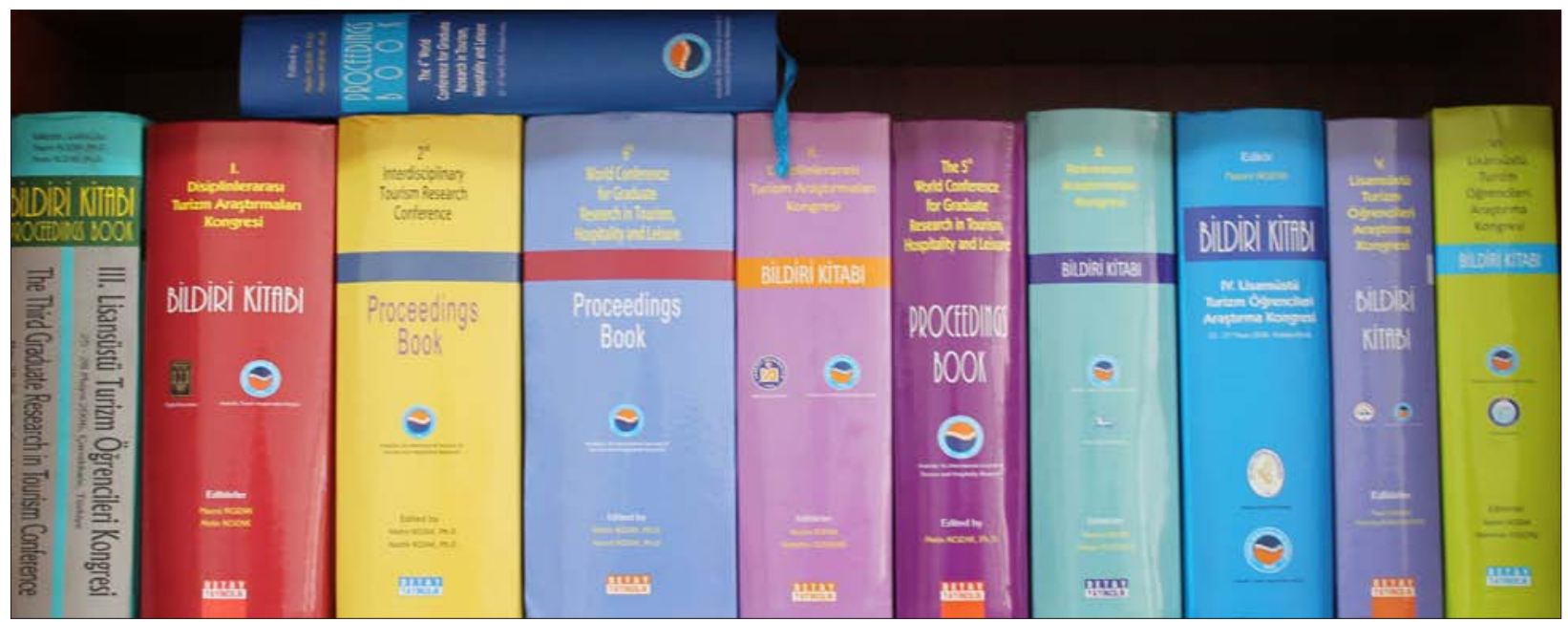

Fotoğraf 25. Anatolia turizm kongrelerinde şimdiye kadar yayımlanan bildiri kitapları (2006-2012 arasında 11 kitap) 


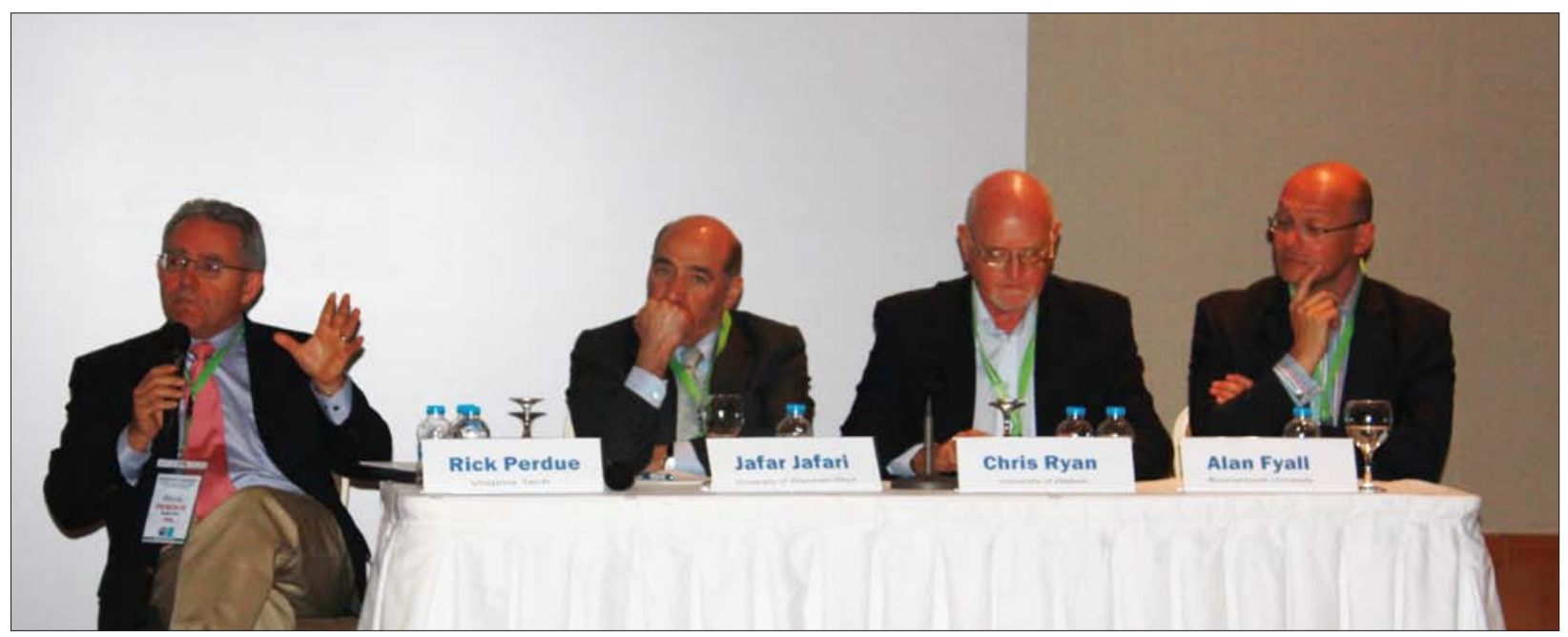

Fotoğraf 26. VI. World Conference for Graduate Research in Tourism Hospitality and Leisure'de bir panel (25 Nisan 2012, Fethiye). (Soldan sağa: Prof. Dr. Rick Perdue, Prof. Dr. Jafar Jafari, Prof. Dr. Chris Ryan ve Prof. Dr. Alan Fyall).

ları arasında akademik turizm kurumlarında konferans ve paneller düzenlendi.

\section{Uluslararası Turizm Karikatürleri Yarışması: 2009} yılında merhum Prof. Atila Özer, Fehmi Köfteoğlu ve bu satırların yazarının işbirliğiyle düzenlenmeye başlandı. Yarışmanın bu yıl beşincisi düzenlenmekte olup, her yarışmaya ortalama olarak 65 ülkeden 700 dolayında eser gönderilmektedir. Ülkemizin sanatsal tanıtımına katkıda bulunmayı amaçlayan yarışmanın iki düzenleyicisinden biri Anatolia: Turizm Araştırmaları Dergisi'dir.
World Conference for Graduate Research in Tourism Hospitality and Leisure: IIlk kongre 2006 y1lında Çanakkale'de, Lisansüstü Turizm Öğrencileri Kongresi ile birlikte gerçekleştirildi. İki yılda bir düzenlenen kongre 2008 y1lında Antalya'da, 2010 yılında Nevşehir'de ve 2012 yılında da Fethiye'de yapıldı. Kongre 2014 yılında İstanbul'da düzenlenecektir. "World Conference for Graduate Research in Tourism Hospitality and Leisure" dünya genelinde düzenlenen benzer üç kongreden biridir. Kongre, lisansüstü tez çalışmaları ve araştırma bildirileri olmak üzere iki kısımdan oluşmaktadır.

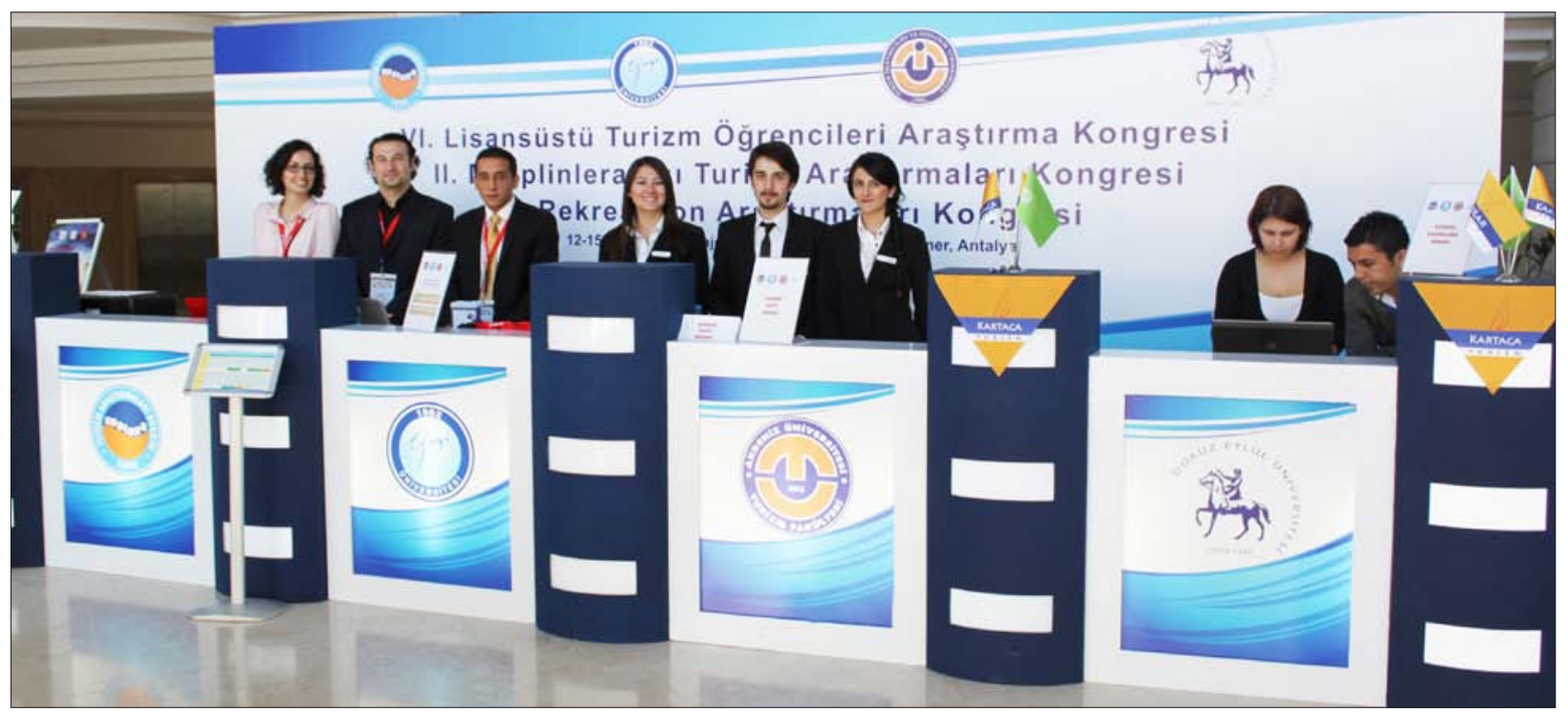

Fotoğraf 27. Anatolia turizm kongreleri karşılama standı (12-15 Nisan 2012, Kemer, Antalya). 


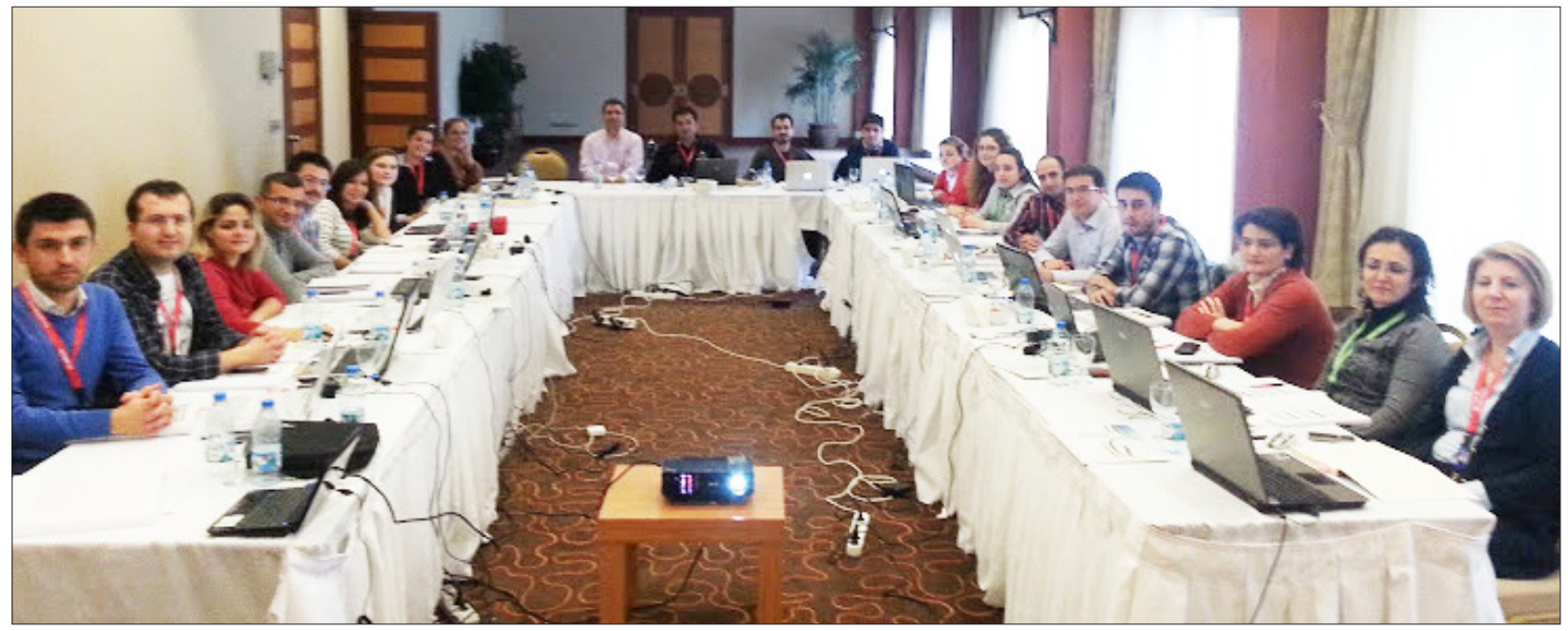

Fotoğraf 28. 11. Araştırma Yöntemleri Semineri'ndeki 10 sınıftan birinde katılımcılar ders başında (13-17 Şubat 2013, Afyonkarahisar)

\section{ULUSLARARASI DERGI: ANATOLIA: AN INTERNATIONAL JOURNAL OF TOURISM AND HOSPITALITY RESEARCH}

Anatolia: Turizm Araştırmaları Dergisi' nin 25 yıllık yayın yaşamının en önemli çıktılarından biri, uluslararası Anatolia'dır (Anatolia: An International Journal of Tourism and Hospitality Research). Anadolu: Turizm Araştırmaları Dergisi'nin 1990-1997 yılları arasindaki yayıncılık deneyiminin bir ürünüdür."Niye bizim ülkemizde de uluslararası bir turizm araştırmala$r$ dergisi yok?" düşüncesi, uluslararası Anatolia'nın yayımlanmasına etkide bulunmuştur. Dergi 1997 yılında yayımlanmaya başlandı. Başlangıç yıl- larında ABD'den Dr. Sevil Sönmez ve Dr. Ercan Sırakaya'nın destekleri ile yayınlanmaya başlayan dergide, Dr. Metin Kozak de eş editör olarak görev aldı. Tıpkı Anatolia: Turizm Araştırmaları Dergisi'nde olduğu gibi birtakım sıkıntılar, başka finansman sorunları olmak üzere yaşandı. Buna karşın derginin uluslararası alanda kabul görmesi Anatolia: Turizm Araştırmaları Dergisi'ne oranla oldukça kısa bir sürede gerçekleşti. Anatolia: An International Journal of Tourism and Hospitality Research, 2005 yılından itibaren birtakım yayınevlerinin dikkatini çekmiş, söz konusu yayınevlerinin dergiyi kendi bünyelerine alma talepleri olmuştu. 2010 yılında Francis and

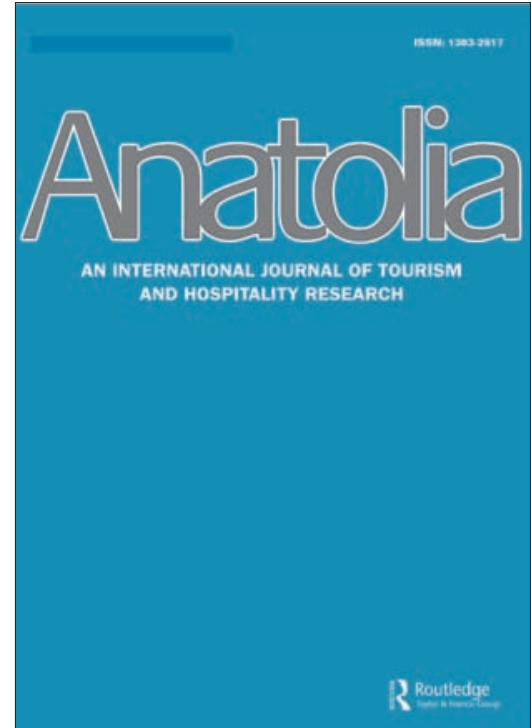

Fotoğraf 29. Uluslararası Anatolia Dergisi

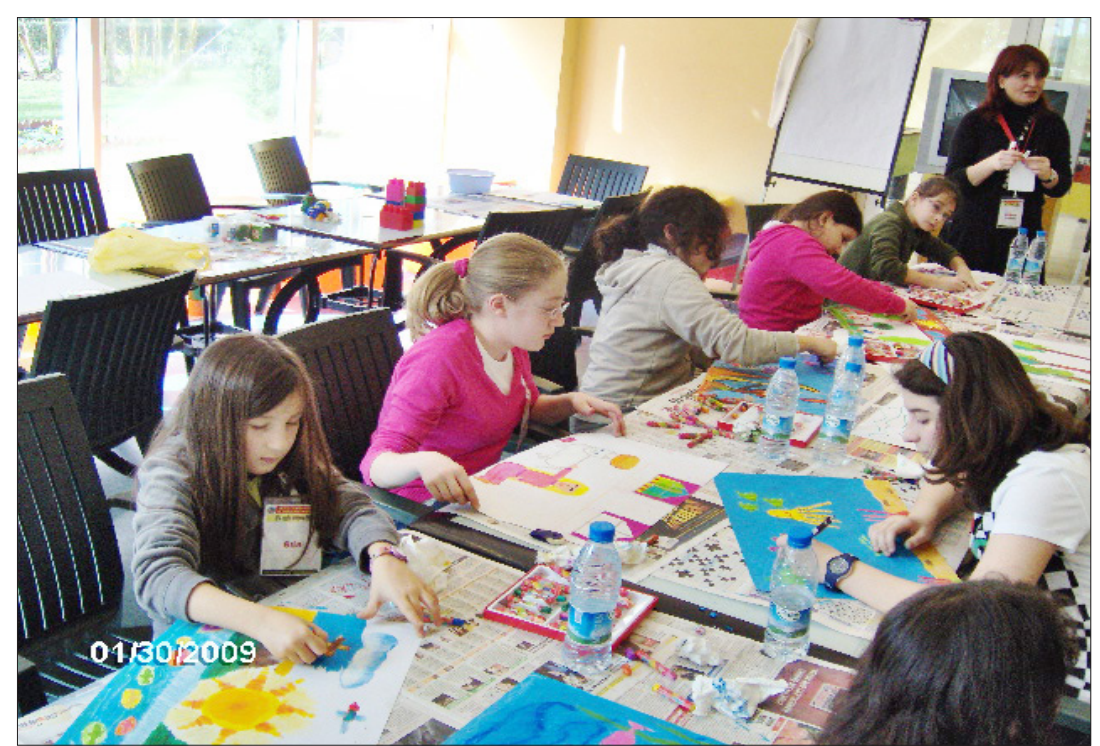

Fotoğraf 30. Seminer katılımcılarının çocukları da resim kursunda (2010). 


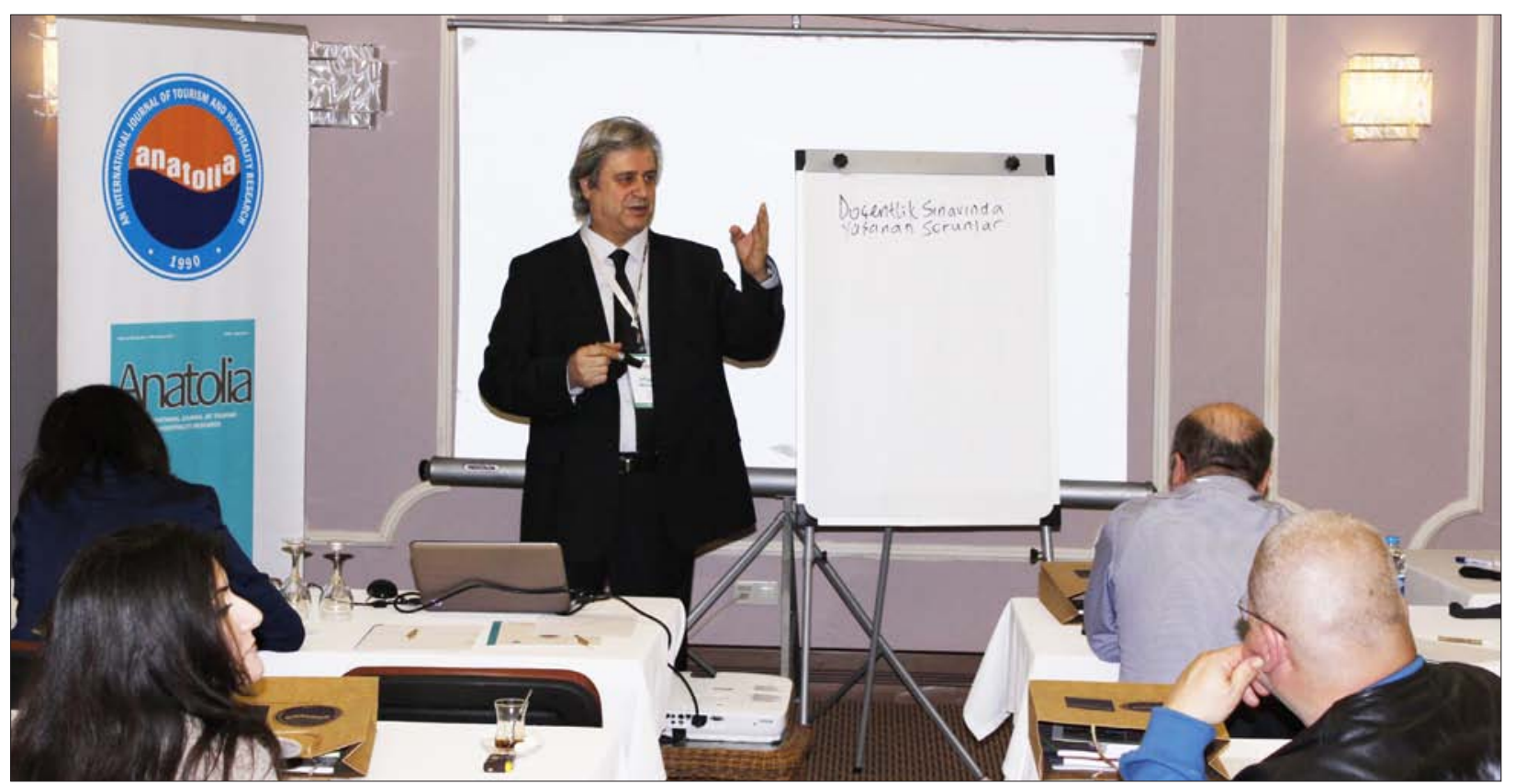

Fotoğraf 31. 5. Araştırma Yöntemleri Semineri'nde Dr. İrfan Misırlı toplantıyı yönetiyor (11-14 Nisan 2013, Manavgat).

Taylor yayıncılık firması ile anlaşılmış ve bu tarihten itibaren dergiyi İngiltere menşeili bu firma yayımlamaya başlamıştır. Anatolia: An International Journal of Tourism and Hospitality Research de Anatolia: Turizm Araştırmaları Dergisi'nin ulusal boyutta gerçekleştirdiği gibi, uluslararası alanda gerek yayıncılık anlayışı ve gerekse düzenlediği iki uluslararası kongre ile farklı bir konuma sahiptir.

\section{DERGININ GELECEĞi}

Anatolia: Turizm Araştırmaları Dergisi'nin geleceği konusu ara sıra gündeme geliyor. Aslına bakılırsa, Anatolia'nın ilk sayısı 1990 yılında yayımland1ğında da bu derginin 25 yıl yayımlanacağına bu satırların yazarı da dahil olmak üzere hiçbir kimse inanmazdı! Koşullar, bazı dostlarımız ve bu satırların yazarının inancı Anatolia'nın 25 yıl yayımlanmasını sağladı denilebilir! Bundan sonra ne olacağ1 da bu cümle üzerinden yorumlanabilir.

$\mathrm{Bu}$ konuda net bir şey söylemek zor olsa da Anatolia'nın üstendiği misyonun gereklerini yerine getirmeye devam etmesi öngörülmektedir. Daha kaç yıl yayımlanır, bilinmez. Ancak bu satırların yazarının amacı bayrağın, başkalarına devredilerek taşınmasıdır. Son yıllarda bu satırların yazarını umutlandıran gelişmeler vardır. Örneğin bir dönem doktora öğrencim de olan Dr. Çağ 11
Hale Özel'in yardımcı editör olarak gayreti ve azmi, beni tekrar umutlandiran unsurlardan biridir. Hale'nin hem iyi bir dergi editörü olma yolundaki ilerleyişi hem de bayrağı taşımaya gönüllü oluşu, buna başkalarının da ekleneceğine olan inancımı artırmaktadır.

Öte yandan, birkaç yıldır görev yaptığım kurumda oluşan akademik ortam da nicedir unuttuğum akademik bir kültürü anımsamama yol açtı. Hacettepe Üniversitesi'nde ve bu dergiyi çıkarmaya başladığım dönemdeki heyecanlı, ilkeli ve samimi akademik kültürün yakın çevremdeki akademisyen ve lisansüstü öğrencilerde de oluşmakta olduğunu görmek, Anatolia'nın geleceği ile ilgili umutlarımı artırıyor.

\section{DEĞERLERDIRME}

Anatolia, ne ülkemizde ne de dünyada eşine pek rastlanmayacak işleri başaran bir dergiden öte bir vak'adır. Öyle sanıyorum ki, yukarıda özetlemeye çalıştığım girişimlerin, hem de yıllarca gerçekleştirilmesi, akademik kurumların dahi üstesinden gelmekte zorlanacakları işlerdir. Anatolia bünyesinde 11 araştırma yöntemi semineri (aslında 50'den fazla seminer!), 30'dan fazla kongre (100'den fazla oturum!), beş akademik turizm eğitimi arama konferansı, biri ulusal, diğeri uluslararası iki bilimsel 
dergi, sanat faaliyetleri, akademik kültürün oluşturulmasına yönelik etkinlikler olmak üzere, ulusal ve uluslararası alanda kolay kolay silinemeyecek işler kotarıldı. Uluslararası Anatolia, "bizden bir şey olmaz" görüşünü çiğnercesine "istenirse bizden bir şeyler olabileceğini" kanttladı, ülkemizdeki pek kişinin uluslararası dergi yayımlama girişiminde bulunmasına öncülük etti.

Öte yandan, turizm pek çok kişi tarafından ciddiye alınan bir alan olarak kabul görmezken, aynı kişiler Anatolia'nın etkinliklerini tıpkısıyla rahatlıkla kopya edebiliyorlar! Bu durum bazen öyle boyutlara ulaşıyor ki, Anatolia'nın düzenlediği kongre ve dergi isimlerinin önüne ve arkasına eklemeler yapılarak yeni etkinlik ve dergi isimleri türetilmesine kadar götürülüyor! 2002 yılında ülkemizde düzenlenen lisansüstü öğrencilere yönelik bilimsel etkinlik sayısı bir elin parmağını bulmaz iken şimdilerde 100 'den fazlası gerçekleştiriliyor. Düne kadar pek çok üniversitede araştırma yöntemleri pek gündeme değil iken son ylllarda hemen her kongrede mutlaka bir araştırma yöntemi oturumu, semineri yapılıyor. Üniversiteler araştırma yöntemleri alanında seminer düzenler hale geldiler.

Anatolia lisansüstü kongreler düzenledi, bu tür kongrelerin sayısı arttı; disiplinlerarası kongreler düzenledi, disiplinlerarası kongrelerin sayısı arttı; araştırma yöntemleri seminerleri düzenledi, araştırma yöntemleri ile ilgili seminerlerinin sayısı art$\mathrm{t}$; uluslararası kongreler düzenledi, turizm alanında bile pek çok uluslararası kongreler düzenlen- meye başlandı. Uluslararası dergi yayımlandı, bir kısmının uluslararası olma özelliği epey tartışmalı da olsa birtakım uluslararası dergiler yayımlanmaya başlandı!.. Anatolia'nın böylesine yüksek bir çarpan katsayısı var...

Anatolia ismi öylesine bir marka haline ulaştı ki, yayıncımız Detay Yayıncllık'ın sahibi Hüseyin Yıldırım, "Detay" unvanının yanına "Anatolia" yı da eklemeyi uygun gördü. Ancak, şu unutulmalıdır ki, Anatolia ismi bu satırların yazarıyla ilintili bir markadır, bir başkasının elinde aynı değeri bulacağ 1 şüphelidir. Elbette ki, Anatolia ismini konumlandıran unsurlar arasında dostlarımızın yanı sıra aile üyelerimiz de bulunuyor. Ender karşılanacak bir durum ile aile üyelerimizden turizm alanında üç öğretim üyesi çıkmıştır. Bu satırların yazarının dışında, Prof. Dr. Metin Kozak ve Prof. Dr. Meryem Akoğlan Kozak'ın Anatolia isminin yerleşmesinde yadsınamaz katkıları oldu; her zaman bu oluşuma önemli katkılarda bulundular. Zaten Prof. Dr. Metin Kozak, uluslararası Anatolia'nın 15 yıldır editörüdür ve uluslararası kongrelerin başkanlığını başından beri yürütüyor.

\section{SON SÖZ}

Bu yazıda Anatolia'nın 25 yılının öyküsünü anlatmaya çalıştım. Mutlaka eksik tarafları oldu, ama fazlası yok, bundan eminim! Bu öykü burada biter mi, bilinmez. Ancak her öyküsünün başı olduğu gibi bir de sonu vardır!..

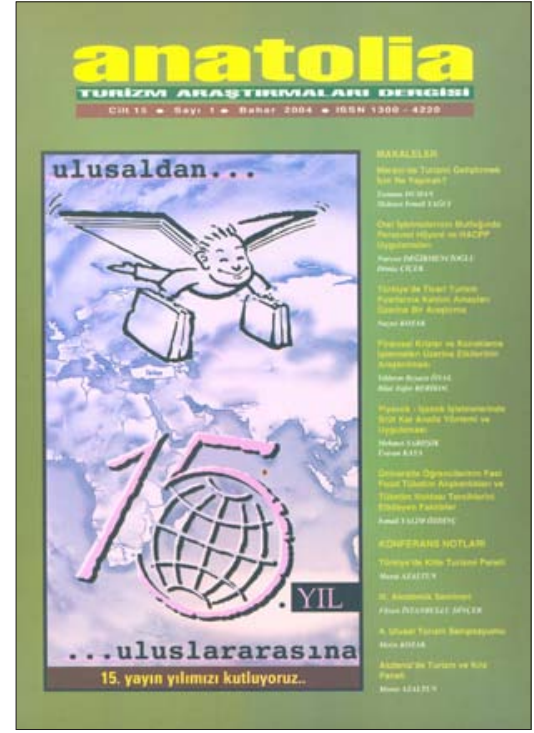

Fotoğraf 32. Anatolia'nın Bahar 2004 sayısı.

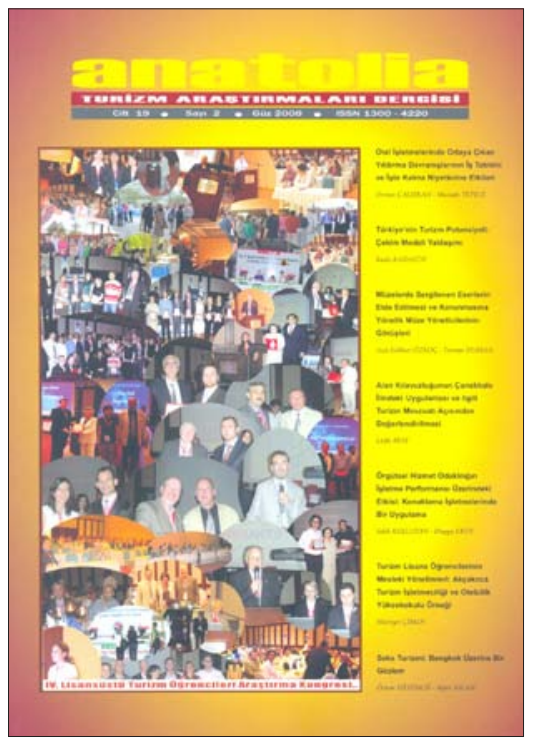

Fotoğraf 33. Anatolia'nın Güz 2008 sayısı.

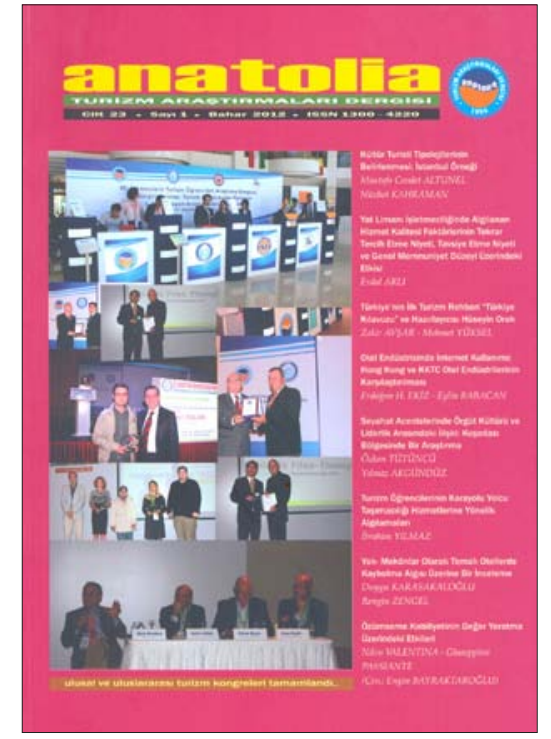

Fotoğraf 34. Anatolia'nın Bahar 2012 sayısı. 